\title{
Goter på drift \\ Reflektioner kring ett försvunnet monument
}

\section{Hans Hägerdal}

Den som besöker dagens Istanbul, gårdagens Konstantinopel, behöver som bekant inte leta länge efter monument från stadens ståtliga östromerska förflutna. Kyrkor, viadukter och segermonument vittnar ännu om metropolens äldsta tid som huvudstad i Östromerska riket, sida vid sida med det myller av arkitektoniska stilar som avlöst varandra under byzantiner, latinare, osmaner och kemalister. Samtidigt får vi komma ihåg att det mesta av monumentalarkitekturen är borta sedan länge. Monument har förfallit, byggnader har fått lämna plats åt nya lösningar. En idé om vad som fortfarande existerade för några få sekler sedan kan man få i de illustrerade verk som antikvariskt intresserade européer gav ut under tidigmodern tid (i runda slängar perioden mellan den osmanska erövringen och franska revolutionen). Ett praktverk var Anselmo Banduris massiva Imperium orientale (1711) som innehöll mycket information om byzantinsk historia och antikviteter, tyvärr, för moderna läsare, avfattat på klingande latin.

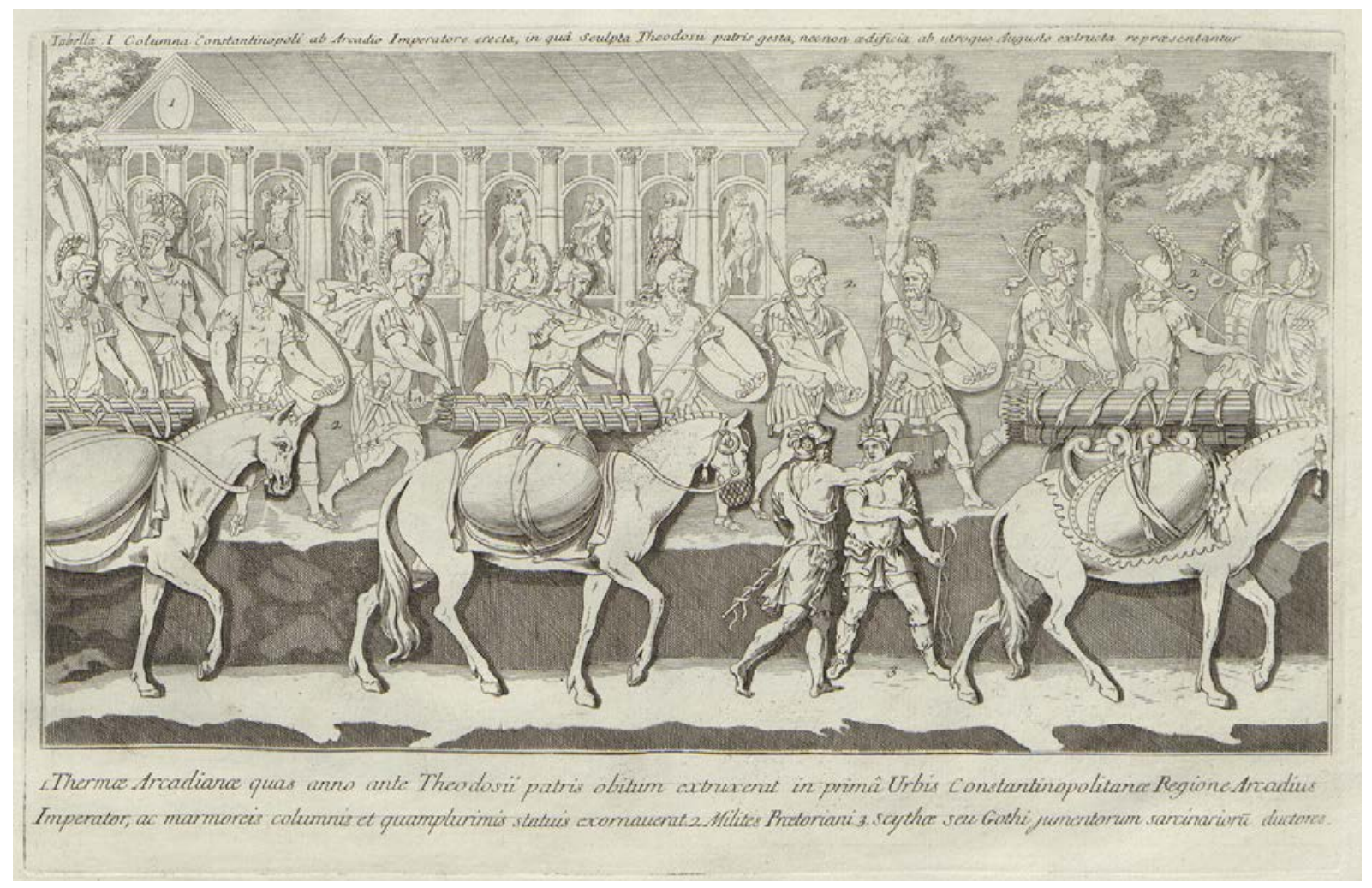

Bild 1. Första planschen i bildsviten om det konstantinopelska triumftåget. Hästsvenner med pittoreska mössor driver packdjur med krigsbyte bestående av sköldar och spjut.

Bland myllret av uppgifter och illustrationer i Banduris verk fästs läsarens uppmärksamhet på en serie om 18 planscher med kopparstick som avbildar en antik relieffris. Relieferna är i sanning spektakulära. Ett romerskt triumftåg drar genom en stad som tydligen 
är Konstantinopel. Svenner i originella hattar driver hästar och kameler, och till och med en elefant, genom metropolens gator medan en nästan uteslutande manlig publik begapar skådespelet. Djuren tycks lastade med krigsbyte som mest består av sköldar och spjut. Soldater i paraduniformer marscherar fram i blandad ordning. En beriden fältherre med stav är i färd att passera en triumfbåge - kan det rentav vara kejsaren i hög person? Men ett triumftåg behöver också besegrade fiender att visa upp, och sådana förekommer av bägge könen och i alla åldrar.

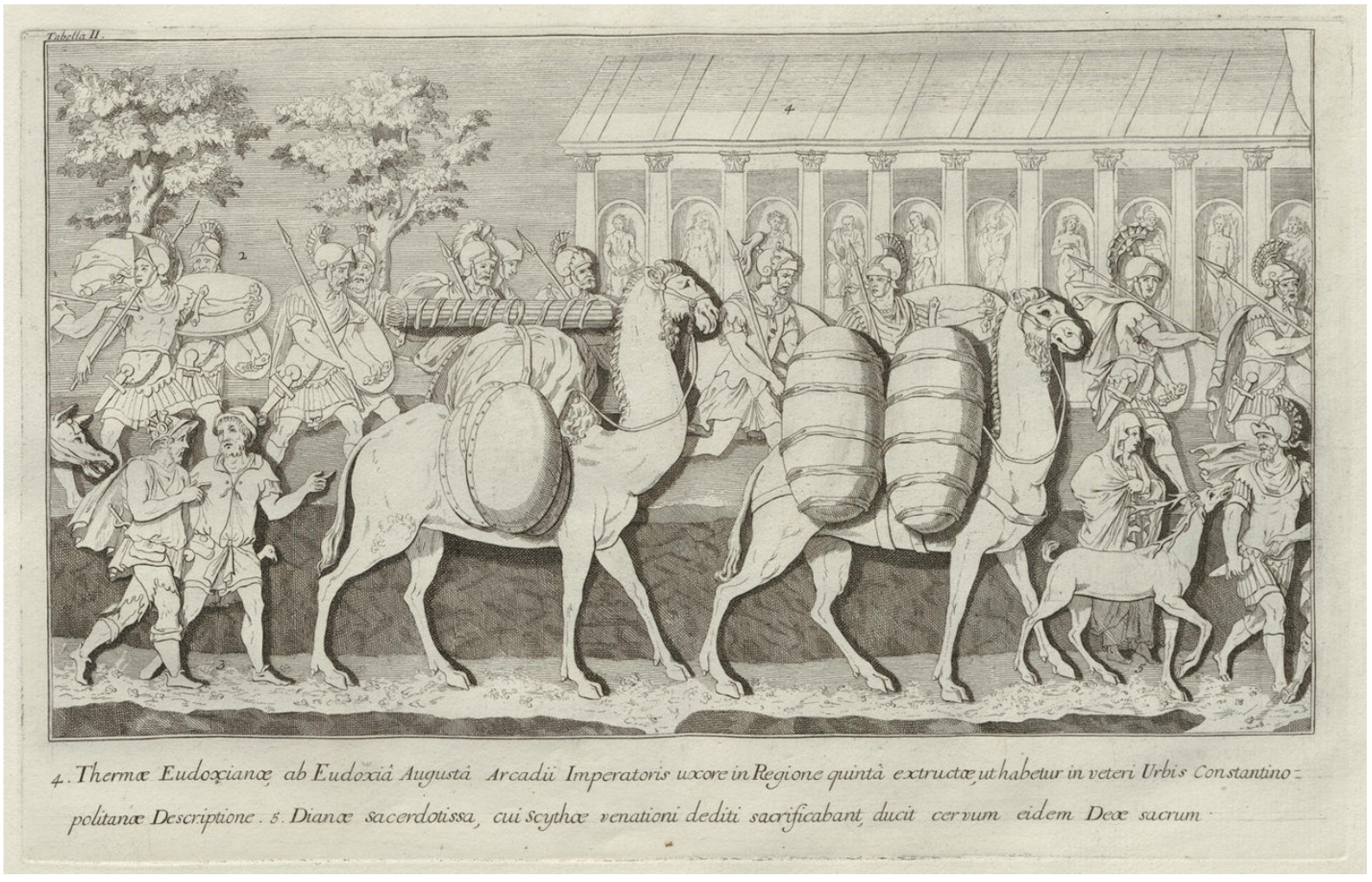

Bild 2. Kameler lastade med krigsbyte drivs längs huvudstadens gator.

Vad är det då för folk som lunkar fram längs gatorna, ibland med bakbundna händer, ibland med händerna fria och livligt gestikulerande? Deras fysionomi påvisar dem genast som barbarer i bemärkelsen människor som härstammade från länderna norr om den befästa gränsen, limes. Romersk konst vimlar av barbarbilder i form av reliefer, myntbilder och statyetter och attributen är omisskännliga. Deras långa hår, skägg, vida tunikor och byxor visar att den som designat relieferna tänkt på icke-romerska motståndare, snarast germaner.

Vi ska komma tillbaka till detaljerna i dessa avbildningar. Tills vidare kan vi fråga oss vilken förlaga kopparsticken hade, hur gammal förlagan är och vilken händelse som egentligen avbildas. Bilderna kan inte sägas vara allmänt kända för en modern publik. De förekommer nästan aldrig i textböcker om Romarriket eller folkvandringstiden trots sin detaljrikedom och konstnärliga kvalitet. Trots detta har de varit föremål för livliga diskussioner bland konstvetare och antikvetare. Mycken trycksvärta har ägnats åt de 
gåtfulla bilderna i böcker och artiklar om senromersk plastik. Några definitiva svar har man inte enats om. Vad jag kommer att göra i denna artikel är dels att referera denna diskussion, dels att teckna den historiska bakgrunden till den händelse som kopparsticken skildrar, och dels att se lite närmare på hur så kallade barbarer skildrades av romerska konstnärer och författare - och om de verkligen skilde sig så mycket från romarna som man brukar föreställa sig.

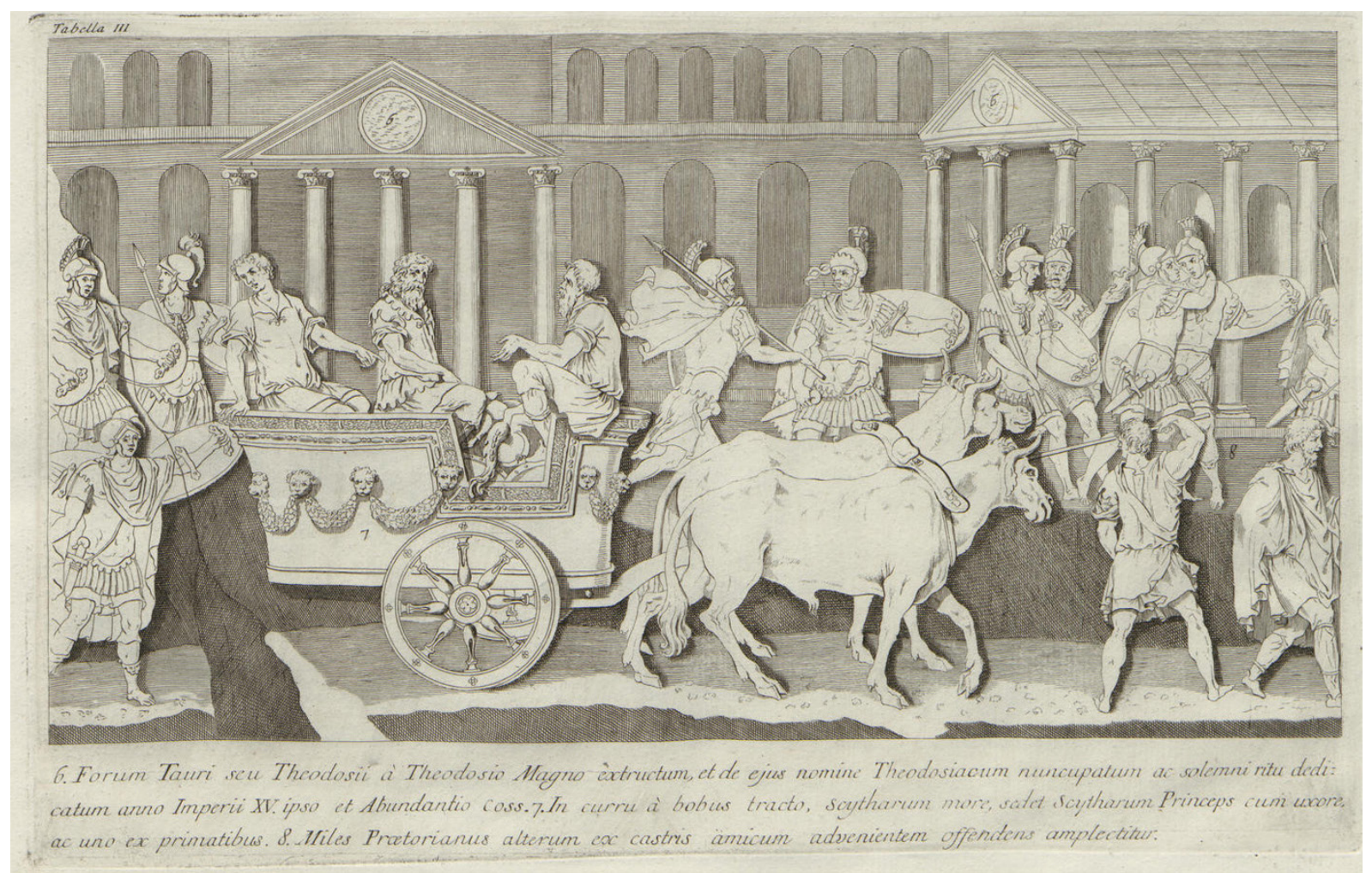

Bild 3. En barbarhövding och hans män sitter på en oxdragen vagn.

Redan 1700-talets antikvetare var oense om var bilderna kom ifrån. Anselmo Banduri ansåg att de härrörde från en kolonn som kejsar Arcadius (395-408) låtit tillverka och som stod på det forum som bär hans namn. Denna kolonn förföll undan för undan och drogs till slut ner av myndigheterna år 1715 eftersom den hotade de kringliggande husen. Idag finns bara basen kvar, kantstött och hopklämd mellan hus. Det finns några avbildningar av kolonnen som dock inte återger relieffigurerna i detalj. Banduris samtida Claude-François Ménestrier hade dock en annan åsikt. Han gav likaledes ut en serie kopparstick under den koncisa titeln Columna Theodosiana quam vulgo historiatam vocant ab Arcadio Imperatore Constantinopoli erecta in honorem imperiatoris Thedosii junioris a Gentile Bellino delineata (1702). Som framgår av titeln ansåg han att bilderna härrörde från en kolonn som Arcadius fader Theodosius den store (379-395) låtit resa. $\mathrm{Nu}$ finns inte heller denna kolonn kvar i sinnevärlden eftersom den tycks ha raserats redan på 1500-talet, även om en del fragment har bevarats. Vad som däremot finns bevarat 
(om än i mindre grad än vi velat) är ett antal antika historietexter som visar att både Theodosius och Arcadius hade händerna fulla med "barbariska” motståndare, närmare bestämt goterna. Ur den synvinkeln borde det rimligen vara gotiska fångar vi ser på kopparsticken. ${ }^{1}$

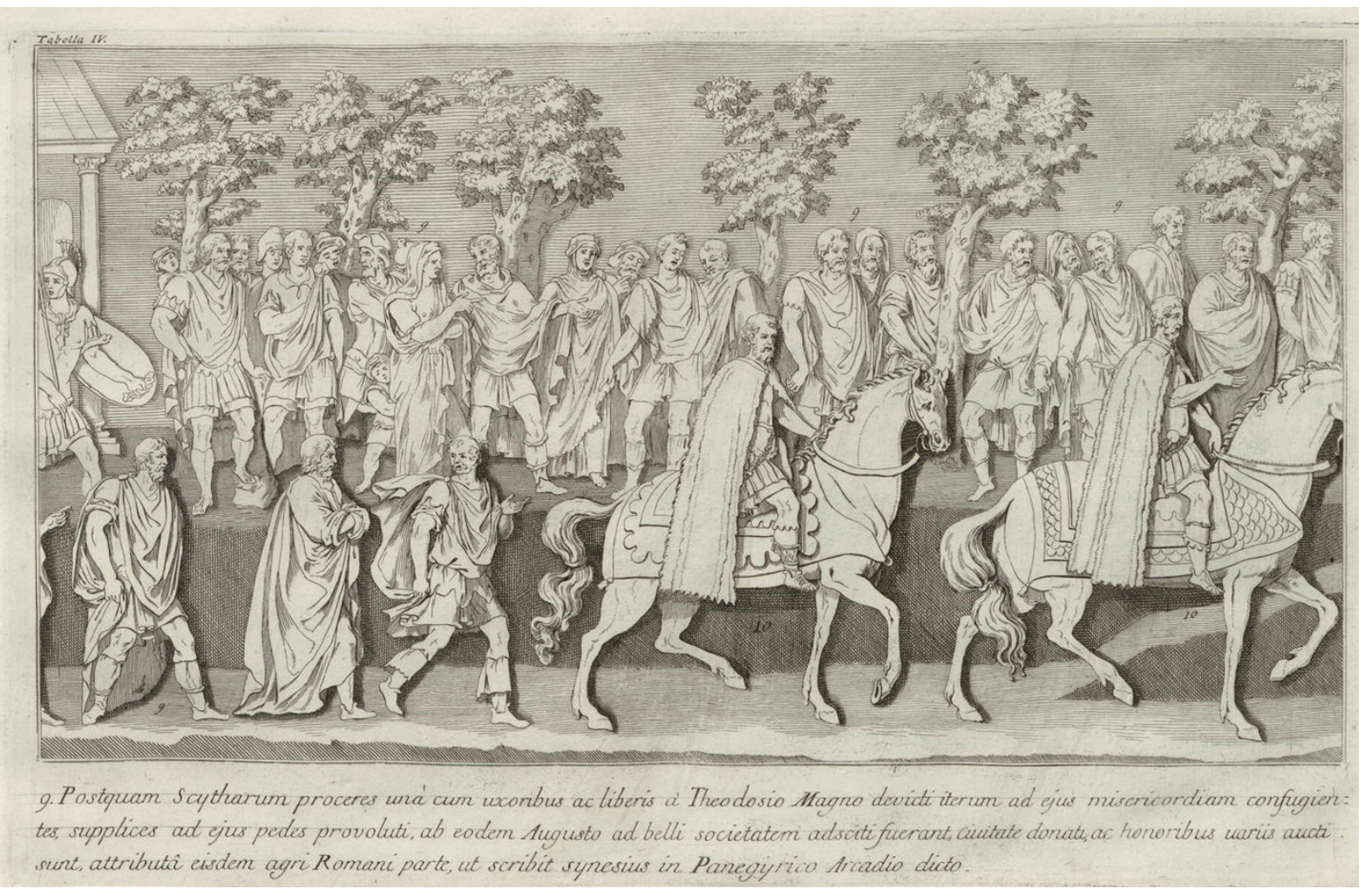

Bild 4. Fångna barbarer går i tåget bakom pälsklädda ryttare medan Konstantinopels befolkning ser på.

Det vi också vet är vilken Banduris och Ménestriers omedelbara förlaga var. Eller rättare sagt är, eftersom den fortfarande finns i gott behåll. I Louvren befinner sig en lång bildrulle på 52 fot vilket betyder så mycket som 14,65 meter. $^{2}$ Den framställer det konstantinopelska triumftåget och överensstämmer tämligen exakt med böckernas kopparstick. ${ }^{3}$ Bildrullens historia kan spåras tillbaka till 1676 då den ägdes av Académie royale de Peinture et de Sculpture. Men som även framgår av titeln på Ménestriers bok skulle den från början ha tecknats av ingen mindre än den berömde renässanskonstnären Gentile Bellini (död 1507). Här öppnar sig nya spännande frågeställningar. Bellini målade de venetianska dogernas officiella porträtt vilket gav honom en hög status bland stadens konstnärer. 26 år efter sultan Mehmed II:s erövring av Konstantinopel slöts en fred mellan Venedig och Osmanska riket, till Venedigs nackdel. Mehmed var personligen intresserad av den italienska renässanskulturen och ville gärna få sitt porträtt målat. De venetianska myndigheterna gjorde honom till viljes och skickade Gentile Bellini till

1 I bildtexterna till Ménestriers stick talas om "skyter" som ursprungligen var en helt annan folkgrupp. Senare kom skyter att få en allmännare innebörd och associerades ibland med goter.

2 Becatti 1960, sid 111.

3 Denna bildrulle finns reproducerad i Beccati 1960, appendix, illustrationer 77-80. 
Konstantinopel år 1479. Bellini fungerade också som en sorts kulturambassadör. Hans möten med den handlingskraftige sultanen ingår i legendfloran om det despotiska Österlandet. En berömd men (som redan Edward Gibbon påpekade) apokryfisk historia låter sultanen prompt hugga huvudet av en slav för att ge den förmodligen chockade Bellini

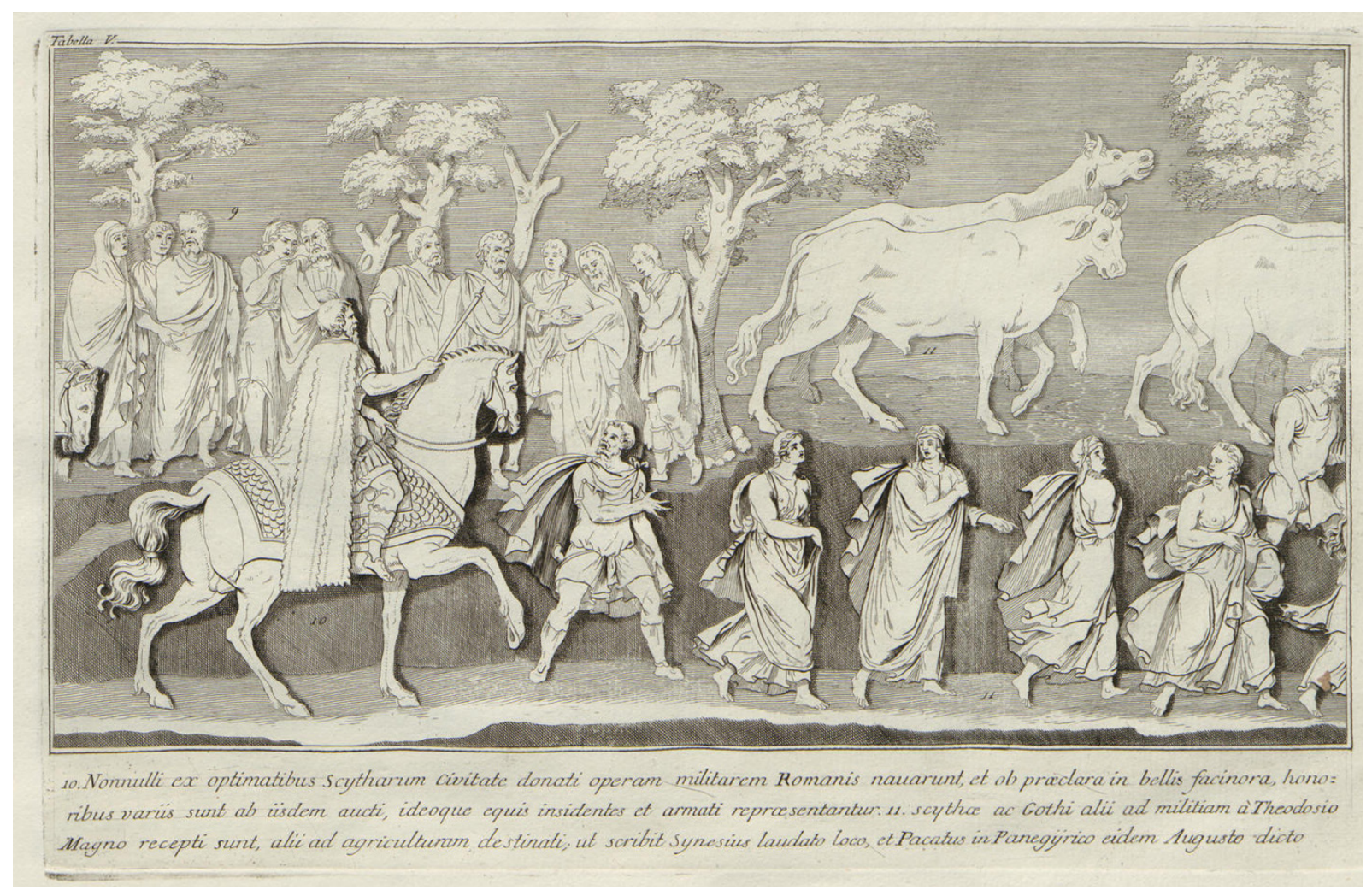

Bild 5. Fångna barbarkvinnor går sida vid sida med boskap.

en åskådlig förlaga för en målning av Johannes döparens död. En målning av Mehmed II kom faktiskt till stånd och hänger numera i Nationalgalleriet i London, även om inte alla är överens om att Bellini verkligen är konstnären. Enligt en senare tradition, känd från 1600-talet, skulle då Bellini ha utnyttjat vistelsen i Konstantinopel till att utföra bildrullen av triumftåget, antingen utifrån Theodosius eller Arcadius kolonner. Bägge bör ha varit i relativt gott skick på hans tid.

Dessvärre kan detta inte vara sant. Även påstått trogna avbildningar har sina stildrag och så är även fallet med bildrullen. Konsthistorikerna har konstaterat att den inte kan vara äldre än 1500-talets sista fjärdedel, kanske ännu något yngre. ${ }^{4}$ Frågan är alltså om det kan röra sig om en 100-150 år yngre kopia av en avbildning av Bellinis hand, eller om Bellinis namn bara har fingerats för att göra historien mer intressant. Vi ska återkomma till frågan om hur bildrullen och kopparsticken ska tolkas. Det är nu dags att säga något mer, dels om hur den avbildade händelsen relaterar till folkvandringstidens historia, och dels hur bildsviten faller in i en romersk tradition av segermonument och germanbilder.

4 Kollwitz 1941, sid 21. 


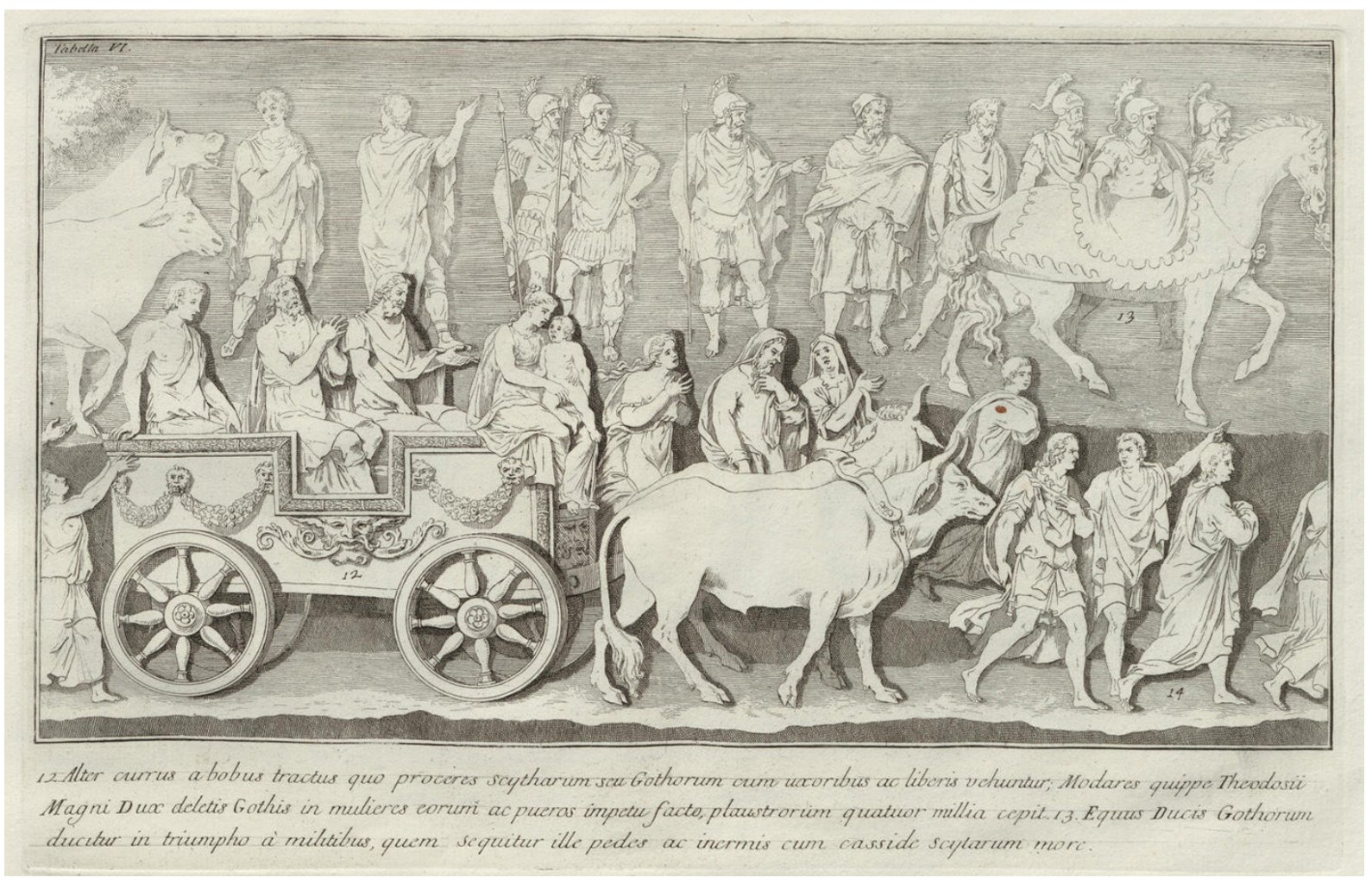

Bild 6. Ännu en hövding fraktas genom gatorna i en vagn, samman med sin kvinna, son och följeslagare.

\section{Migranter från norr}

För människor på 1900- och 2000-talen betyder kanske folkvandringstiden inte så mycket i det allmänna medvetandet. Perioden, som ungefärligen sträcker sig från hunnernas infall i östra Europa 375 till langobardernas invasion av Italien 568, framstår som en svåröverskådlig följd av migrationer och krig som i vedertagen historisk kronologi bildar en buffertzon mellan antiken och medeltiden. Ändå lever perioden kvar i vissa begrepp. Vandaler finns det fortfarande alltför gott om, även om den moderna varianten klottrar tags på husväggar och sparkar sönder busskurer snarare än att idka godsdrift i det som idag kallas Tunisien. Hunner är ett vedernamn som vårt grannfolk söder om Östersjön har fått dras med sedan Boxarupprorets dagar, om än i mindre utsträckning under efterkrigstiden. Anglosaxare får numera beteckna vita engelskspråkiga folk världen över. Och moderna geografiska begrepp som Frankrike, Lombardiet och Bayern vittnar om de folkvandringsstammar som från början gav dem deras namn.

Frågan är dock om inte goterna befinner sig i en klass för sig när det gäller avtryck på senare tiders föreställningar. Detta är en smula förvånande eftersom goter inte funnits som föreställd etnisk grupp sedan 700-talet (med undantag för en liten grupp på Krimhalvön som överlevde in på 1700-talet). Men kanske är det just därför de varit så användbara och kunnat ge upphov till ständigt nya betydelser, fram till dagens svartklädda gothic-mode. I egenskap av nordliga erövrare av Rom, Italien, Spanien med mera har de varit ett lockande ämne att hänga upp sentida patriotiska 


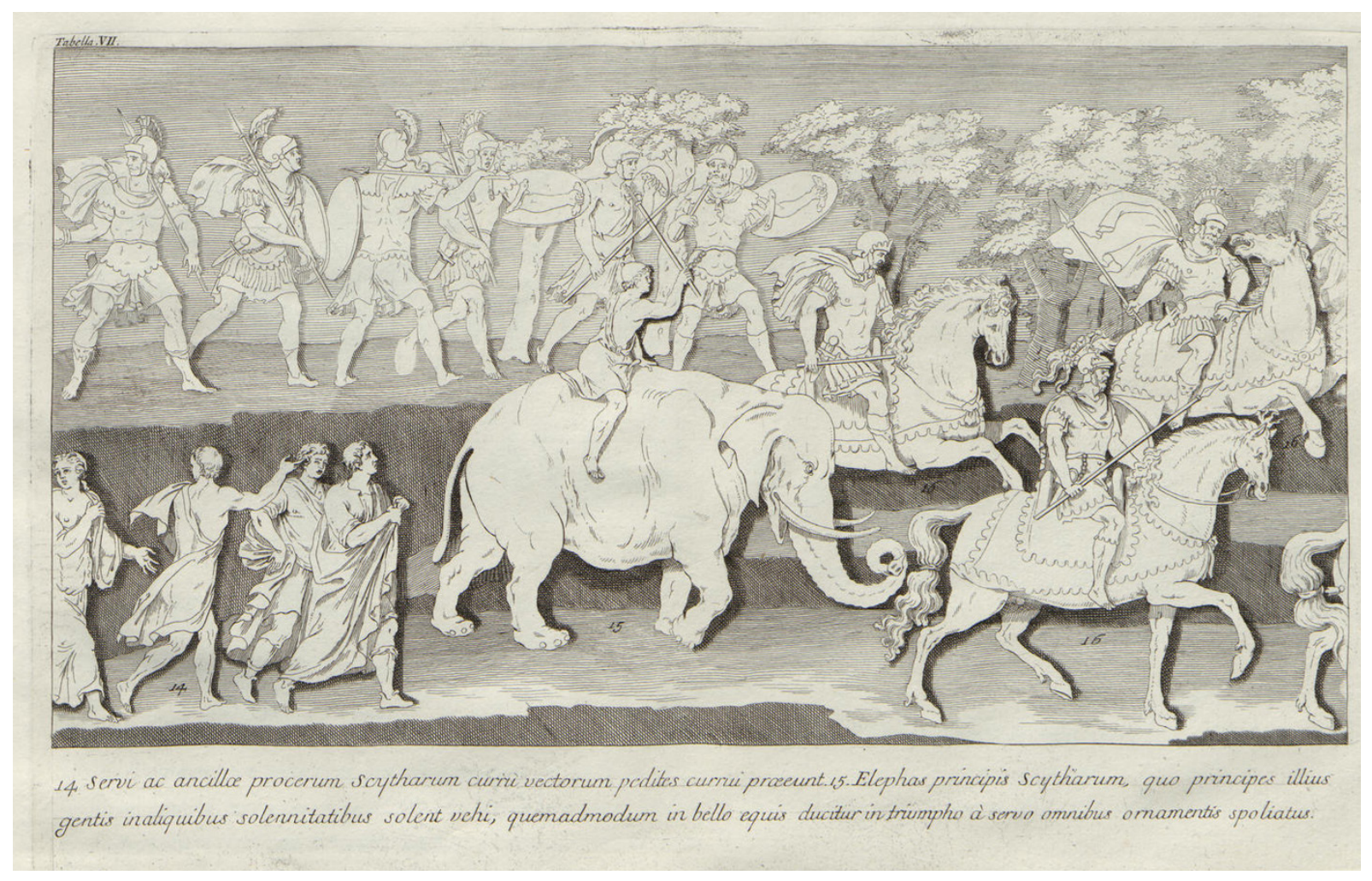

Bild 7. En elefant hör också till sevärdheterna under triumftåget.

föreställningar på. Spanska medeltida och moderna riksbildningar har gärna hänvisat till det gotiska förflutna. I 1800-talets Tyskland med dess frambrytande etniska nationalism framstod goterna som ett ljushyllt och ädelt släkte, epitomiserat i Felix Dahns historiska roman En kamp om Rom - detta trots att de historiskt betygade goterna opererade över nästan hela Europa utom på tysk mark. En sentida populärhistorisk reaktion på den tyska gotervurmen finner vi i fransmännen Albert Uderzos och René Goscinnys seriealbum Asterix och goterna där goterna görs till en sinnebild av 1900-talets tyskar och kännetecknas av militarism och erövringslusta med tydliga kopplingar till Hitler och Förintelsen (i en signifikant scen har goternas hövding blivit informerad om en ny diabolisk avrättningsmaskin och skrockar belåtet, "Vilka framsteg tekniken gör”). I Sverige identifierades goter rutinmässigt med götar fram till åtminstone tidigmodern tid. Under stormaktstiden hade denna goticism en viktig ideologisk betydelse eftersom goternas (och vissa andra folkvandringsstammar med förmodat skandinaviskt påbrå) bedrifter också kunde ses som Sveriges. ${ }^{5}$ Kungen bar den stolta titeln Rex Suecorum Gothorum et Vandalorum och den danske kungen höll sig med en snarlik titulatur. I bakgrunden för sådana yverborna föreställningar ligger i första hand den östgotiske historikern Jordanes skrift Getica (551) som friskt blandar fiktion och fakta. I den berömda och omdiskuterade inledningsdelen av sin krönika härledde Jordanes goternas ursprung till Scandza, det vill säga Skandinavien. ${ }^{6}$

Den arkeologiska vetenskapen ger inte mycket utrymme åt detta. Det är numera vanligt att identifiera goterna med en kultur vid Polens Östersjökust, Wielbarkkulturen som uppkom strax efter Kr.f. Fyndmaterialet med gravar som består av upphöjda stencirklar

5 Behre, Larsson \& Österberg 2001, sid 144-45.

6 Jordanes 1997, sid 41. 
med vidstående uppresta stenar tyder på vissa kontakter med Skandinavien men definitivt inte på att kulturen skulle ha uppkommit genom en skandinavisk invandring. Det är också vid den här tiden som namnet goter dyker upp i de antika källorna. På 100-talet börjar bärarna av Wielbarkkulturen att röra sig åt sydöst. Enligt den gängse tolkningen går de över till en ny kulturform i det som idag är delar av Vitryssland, Ukraina, Moldavien och Rumänien. Det är Tjernjachovkulturen som tycks ha varit etniskt blandad med germanska, slaviska dakiska, getiska och sarmatiska drag. Det skulle i sin tur stämma med en gotisk stamtradition som meddelas i Jordanes Getica, om en migration från havet i norr till slätterna i sydöstra Europa. ${ }^{7} \mathrm{Nu}$ är det inte alla som går med på detta. Det finns de som menar att Wielbark och Tjernjachov inte har med varandra att göra och att det inte fanns någon definierad gotisk folkstam före 200 -talet. ${ }^{8}$ I själva verket skulle goternas uppkomst som etnisk grupp få ses som en biprodukt av förhållandena vid de romerska limes i norr. Det mäktiga Rom inspirerade till att nya stammar bildades av tidigare folkgrupper för att möta den högteknologiska och aggressiva grannen.

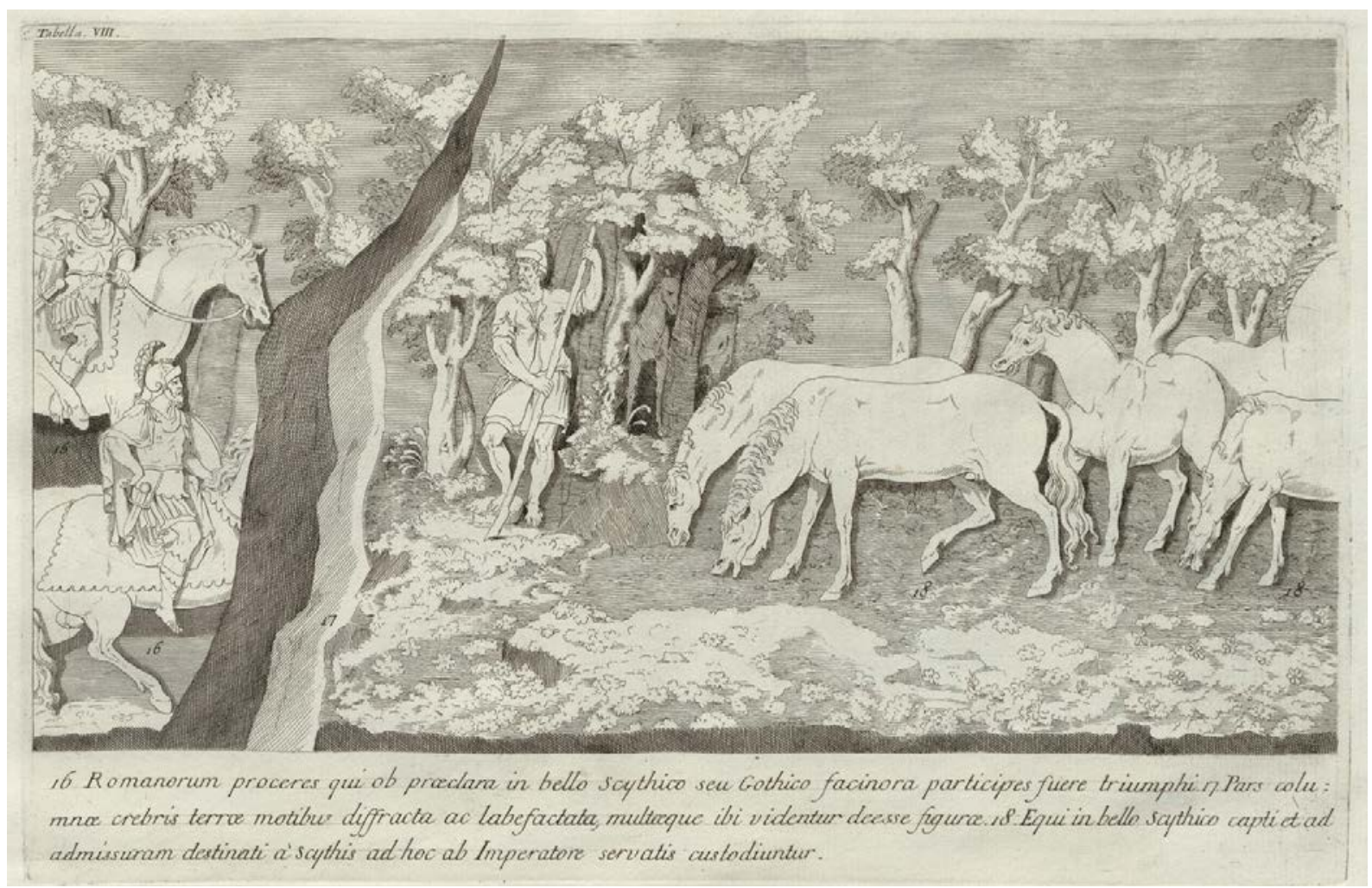

Bild 8. En flock hästar betar, övervakade av en man av oklart etniskt ursprung.

Hur som helst dyker aggressiva gotiska förband upp vid limes en bit in på 200-talet. Från 238 gjorde de infall på Balkanhalvön och kom under de följande seklerna att härja i Grekland och Mindre Asien. Romarriket hade sett sin bästa tid och styrdes vid den här tiden av militärkejsare som med få undantag mördades av sina egna soldater efter några år vid makten. De romerska legionärerna bestod numera i stor utsträckning av

7 Jordanes 1997, sid 41-43.

8 Kulikowski 2007, sid 63-67. 
germaner som väl ibland tänkte mer på egna fördelar än lojaliteten med Rom. En av militärkejsarna, Decius, utkämpade ett stort slag mot en gotisk koalition i nuvarande Bulgarien år 251. Fienden lockade honom och hans armé ut i ett träsk där han stupade med många av sina legionärer. Det var inte längre självklart att den romerska arméorganisationen garanterade seger mot nordliga "barbarer". ${ }^{9}$ En av Decius efterträdare, Aurelianus, drog tillbaka de romerska trupperna från Dakien, nuvarande Rumänien, några år innan han själv mördades av sina soldater år 275. Dakien var ingen riktigt integrerad del av Romarriket och det ansågs vara för kostsamt att hålla området. Istället blev provinsen boplats för en del av goterna. Källor från slutet av 200-talet talar om två olika gotiska grupper som kallades tervinger och greutunger. ${ }^{10}$ Intressant nog har begreppen möjligtvis överlevt i legendarisk form och går igen i den isländska Hervararsagan från 1200-talet som delvis utspelar sig bland goterna. ${ }^{11}$ Sagan har ingen relation till kända historiska händelser men omtalar ett magiskt svärd Tyrfing som bärs av en lång rad generationer heroiska gestalter och vars namn enligt en uppfattning har att göra just med

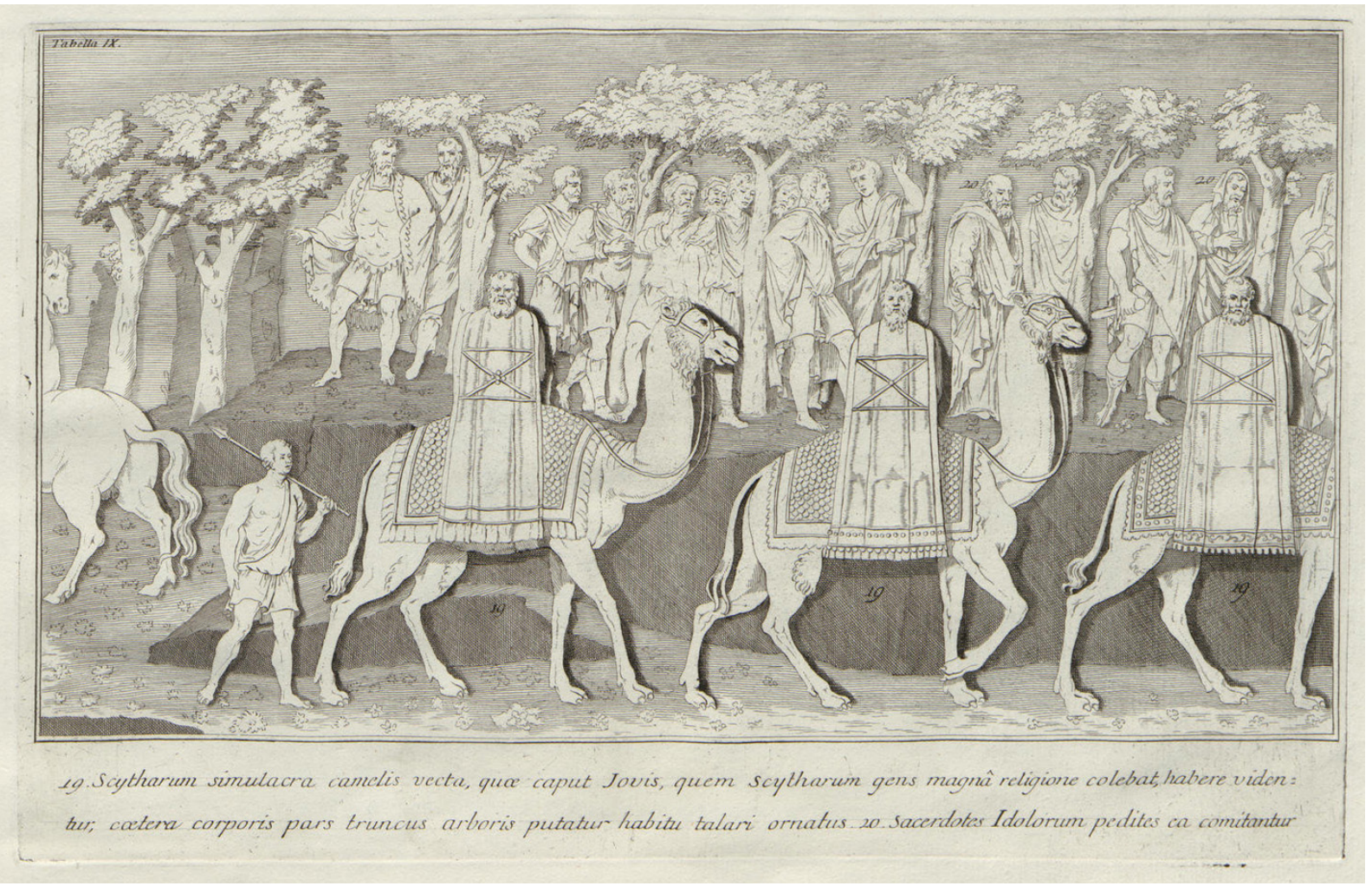

Bild 9. Kameler med bundna hövdingar, eller skall det kanske vara gudabilder?

tervingerna. En av huvudpersonerna vid det gotiska hovet är Gizzur grytingakämpe vars tillnamn kan förknippas med greutungerna. Senare kom tervingerna delvis att överlappa med en annan beteckning, visigoter, under det att greutungernas namn mer eller mindre kom att ersättas med begreppet ostrogoter. På svenska brukar vi sedan gammalt tala om

9 Jordanes 1997, sid 85.

10 Kulikowski 2007, sid 31, 111.

11 Sagan är översatt av Lars Lönnroth 1995. 
västgoter och östgoter trots att de ursprungliga namnen betyder någonting annat. Visigoter eller vesi betyder inget mindre än "de goda” under det att ostrogoter betyder "den uppgående solens goter”, med andra ord "de glänsande”.

Under de följande decennierna hör vi inte så mycket om goter. De hade decimerats svårt av militära nederlag mot romarna och levde dels på den nyvunna marken norr om Donau, dels längre upp mot Ukrainatrakten. ${ }^{12} \AA$ andra sidan är det svårt att säga vilka som ska kallas "goter". De flesta historiker idag tror att germanska folkstammar var flexibla skapelser. Stammar splittrades och uppgick i varandra och det var kanske inte så svårt att glida över från en etnisk identitet till en annan. Svårigheten att beskriva goter och andra germanska stammar ligger i källmaterialet. När vi talar om goternas öden och äventyr tenderar skildringen att bli militär historia eftersom de antika författarna mest

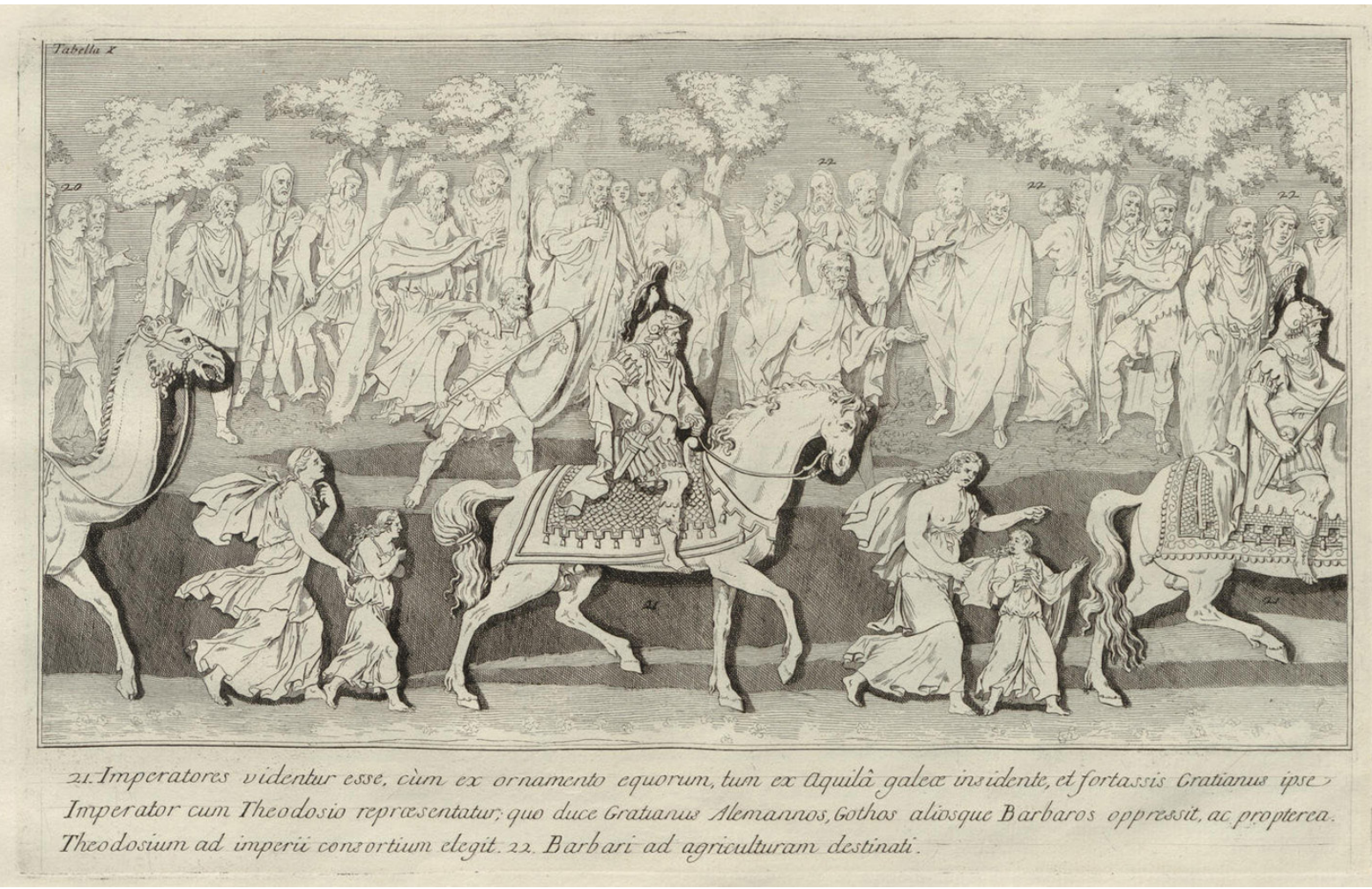

Bild 10. Två höga herrar rider bland kvinnliga fångar. Den främre är tydligen segerherren med stav i handen, kanske kejsaren i egen hög person.

intresserade sig för dem när de stötte samman med Romarriket. Men så snart vi avlägsnar oss från stridslarmet och de diplomatiska förhandlingarna tornar svårigheterna upp sig. Vi vet till exempel nästan ingenting om deras religion även om man får anta att vissa gudar var desamma som dem som dyrkades i Skandinavien under vikingatiden. Arkeologin kan bara delvis fylla ut det tomrum som de skriftliga källorna lämnat.

12 Ett par större sammanstötningar bör dock nämnas. Konstantin den store besegrade goter på andra sidan Donau och slöt en fred med dem år 332, vilket ledde till mer än 30 år av fredliga förhållanden på den fronten. På 360-talet genomförde kejsar Valens fälttåg mot den kristendomsfientlige gotiske hövdingen Athanarik (d. 382); se Kulikowski 2007, sid 84-86, 115-17. 
Det vi vet är att ett stort östgotiskt rike byggdes upp på 300-talet. Arkitekten var en viss Ermanarik. Den enda samtida källan till hans karriär är historikern Ammianus Marcellinus (ca 330-395) som betygar att Ermanarik härskade över ett mycket stort område någonstans i närheten av Svarta havet. ${ }^{13}$ Jordanes, som skrev nästan två sekler senare, hävdar att det var ett multietniskt rike och ger en lista över folkstammar som lydde under härskaren. De flesta är numera okända men stammarna merer och morder tycks motsvara merier och mordviner som idag är två folkslag vid övre Volga, långt in i det inre av Ryssland. Det skulle i så fall betyda att östgoterna för en kort tid kunde hålla uppsyn över ett enormt välde. En del nyare historiker menar dock att nästan allt Jordanes skriver om denna tid är fiktion. ${ }^{14}$ Ermanarik är intressant för det avtryck han har givit i senare tradition. Redan Jordanes berättar legendariska detaljer om hans liv som återfinns

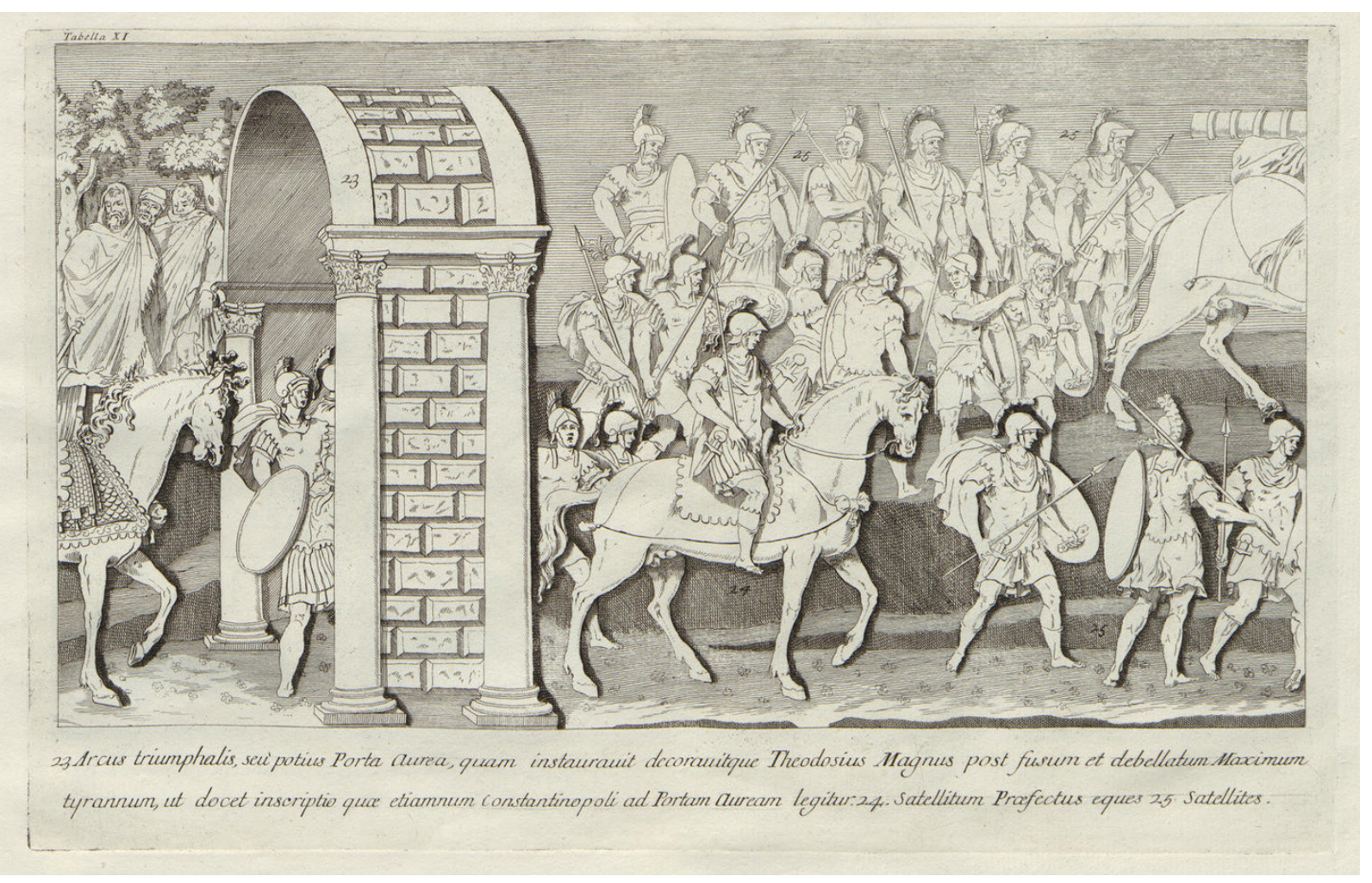

Bild 11. Segerherrens häst är på väg in genom en triumfbåge.

i senare version i anglosaxiska, tyska och skandinaviska texter. I allmänhet går historierna ut på att förklara hans våldsamma ändalykt. ${ }^{15}$

Nu dyker nämligen en ny faktor upp på scenen. Hunnernas härkomst och identitet är om möjligt ännu mindre kända än goternas. Vi vet inte vilket språk de talade, vad de kom ifrån, vilka gudar de tillbad eller ens om de utgjorde en politisk enhet vid sin ankomst till Europa. Möjligen var de turkomongoler och avlägset släkt med de centralasiatiska

13 Ammianus Marcellinus, bok 31, http://www.tertullian.org/fathers/ammianus 31 book31.htm (hämtad 15 november 2014).

14 Kulikowski 2007, sid 112.

15 Jordanes 1997, sid 93-99. 
grupper som på modern kinesiska kallas xiongnu eller hungno. ${ }^{16}$ Men deras våldsamma framfart var påtaglig nog för dem som kom i vägen. De antika auktorerna beskriver dem som frånstötande vildar men visar en motvillig beundran för deras militära kraft och rörlighet. De ridande bågskyttarna från öster stormade in i Ermanariks östeuropeiska rike och välte det snabbt över ända kring 375. Kungen begick självmord och östgoterna underkuvades efter ytterligare motståndsförsök. ${ }^{17}$ De flesta östgoterna fortsatte att leva under hunnernas överhöghet fram till tiden efter den berömde Attilas död 453. Men då är vi framme vid en tid som ligger utanför ramen för denna artikel.

\section{Folkvandringstiden tar sin början}

Med hunnernas seger i Östeuropa börjar en kedja av händelser som bildade motiv för Theodosius och Arcadius triumfbågar i Konstantinopel. Kejsarna Diocletianus (284305) och Konstantin den store (306-337) lyckades med stor ansträngning få det fallerande Romarriket på fötterna efter det turbulenta 200-talets militärkejsardöme. Riket omvandlades till ett självhärskardöme där de kejserliga byråkraterna höll noggrann uppsikt över befolkningen som fråntogs möjligheter till social mobilitet. ${ }^{18}$ Under Konstantin blev kristendomen en viktig komponent för att ena riket under en effektiv religiös ideologi. Därtill insåg han att riket behövde en alternativ huvudstad i den östra riksdelen för att man skulle kunna integrera hela kejsardömet. Så grundlades Konstantinopel 324. ${ }^{19}$ Konstantins söner var inte några märkvärdigare gestalter men hans dynasti regerade fram till 363 och efterträddes av de inbördes besläktade valentinianska och theodosianska dynastierna (364-455). De skulle snart få händerna fulla av de gotiska affärerna.

Med snabbskjutande hunniska ryttare i hälarna började nämligen stora skaror goter att fly från det krigsdrabbade området norr om limes. Västgoterna hade vid den här tiden börjat gå över till den arianska varianten av kristendom genom missionären Ulfilas (död 383) ansträngningar. Den gotiske eller halvgotiske Ulfilas hade rentav introducerat ett speciellt alfabet och översatt Bibeln från grekiska till gotiska. ${ }^{20}$ Det var alltså ur romersk synvinkel inte (bara) oborstade hedningar som knackade på dörren år 376. Kejsarmakten delades vid den här tiden mellan Valens och hans brorson Gratianus som styrde över respektive den östra och västra rikshalvan. Valens hör till de många som hedrats med epitetet "den siste romaren” men anses i övrigt ha varit föga snillrik. Han gick med på att goterna och andra hjälpsökande stammar fick komma över till den relativa säkerheten söder om Donau. ${ }^{21}$ Hans militära resurser var begränsade och de vapenföra migranterna från norr skulle kunna bli ett användbart tillskott i den romerska hären.

16 En annan möjlighet är att de bägge stammarna bar samma eller liknande namn utan att egentligen vara släkt.

17 Ammianus Marcellinus, bok 31, http://www.tertullian.org/fathers/ammianus 31 book31.htm (hämtad 15 november 2014).

18 Jones 975, sid 35-36, 282-98.

19 Jones 1975, sid 49, 231-32.

20 Döbler 1979, sid 603-07.

21 Döbler 1979, sid 584. 
Dessvärre blev situationen snart ohållbar. En källa påstår att en miljon goter och andra flyktingar befann sig vid gränsen i Dakien och Moesien vilket väl är en grov retorisk överdrift. Men människoskaror strömmade snart in på romerskt territorium okontrollerat. Moderna historiker antar att det allra minst rörde sig om tiotusental. ${ }^{22}$ Därmed säger man traditionellt att folkvandringstiden i Europa tar sin början. Under de följande två seklerna skulle en lång följd av migrationer och krig välta de gamla romerska samhällsformerna överända och grunda nya riken i centrala och västra Europa - även om övergången från "antik” till "medeltid” är en godtycklig konstruktion av senare historiker.

I de flyktingläger som formades söder om gränsen var förhållandena miserabla och saken blev inte bättre av att lokala romerska officerare utnyttjade flyktingarnas utsatta situation till sin fördel. De behöll mattransporter och delade bara ut livsmedel till utsugarpriser. Föräldrar måste ge sina barn som slavar för att få en smula föda. Den kristne gotiske ledaren Frithigern försökte hålla freden med romarna trots påfrestningarna, men en blodig incident i staden Marcianopolis (i Trakien i nuvarande Bulgarien) där han själv med knapp nöd kom undan med livet gjorde ett tvärt slut på hans tålamod. Frithigern ställde sig i spetsen för en upprorisk skara och alla de goter som flytt över Donau slöt sig till hans led. Ett stycke från Marcianopolis stötte hans skaror ihop med en romersk armé som led ett blodigt nederlag. Goterna försåg sig med de stupades vapen och utrustning och begav sig söderut. Faran med att ha stora kontingenter germaner i de romerska legionerna visade sig när gotiska legionärer slöt sig till de upproriska. På det här stadiet var det vare sig ett målmedvetet krigsföretag eller en folkvandring utan en serie lokala revolter som smälte ihop till ett massuppror. ${ }^{23}$ Att goternas stridsvärde inte borde underskattas visade sig när en ny romersk armé gick löst på fienden vid en numera okänd plats kallad Ad Salices ("pilträden”). Goterna bildade en väl förskansad vagnborg och bet ifrån sig med kraft. Till slut måste romarna ge sig iväg då de hade förlorat alltför många män för att fortsätta striden. Detta inträffade sommaren 377. Nu allierade sig upprorsmännen med grupper av alaner, ett indoeuropeiskt folk med ursprung i norra Kaukasus, och märkligt nog även med vissa hunner. Som vi nämnt var etniska lojaliteter flytande vid den här tiden och gårdagens fiender kunde snabbt förvandlas till medkämpar.

Valens var upptagen med perserna i öster som normalt betraktades som den svårare fienden till Romarriket. Nu fick han dock upp ögonen för att situationen på Balkanhalvön höll på att spåra ur. Från rikets östra provinser hastade han tillbaka till Konstantinopel och drog därifrån ut i fält för att möta faran i juni 378. Med en fältarmé på cirka 30-40 000 man anlände han till Adrianopel som numera heter Edirne och ligger i europeiska Turkiet. I närheten fann hans spejare en gotisk skara på (som de trodde) 10000 man vilket verkade vara en lämplig munsbit för en vältränad romersk här. Ingen verkar ha trott annat än att romarna måste gå segrande ur en sammanstötning och Frithigern sände bud med fredstrevare. Valens ville dock inte låta tillfället till en förintande

23 Kulikowski 2007, sid 136. 


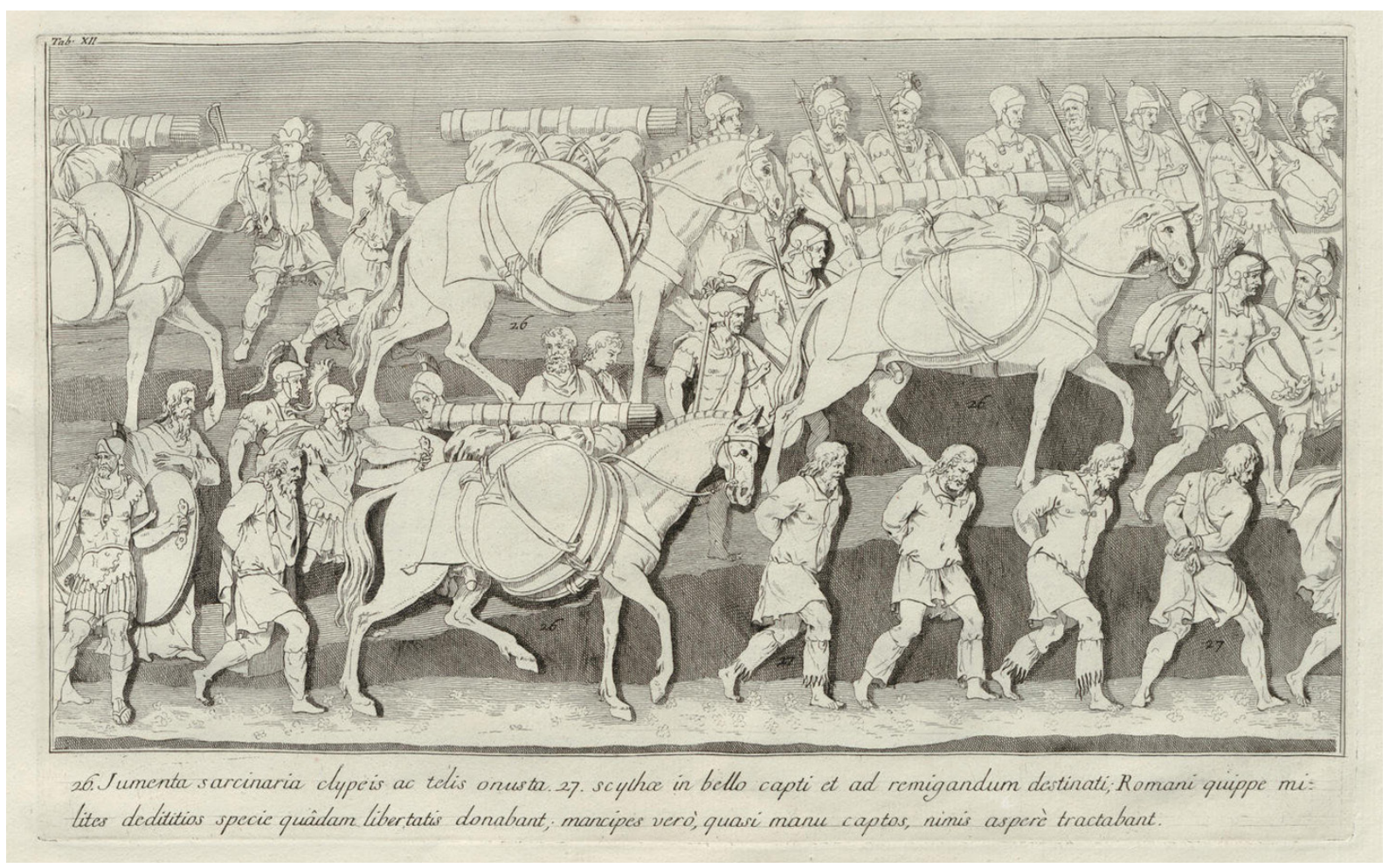

Bild 12. En rad bakbundna barbarfångar lunkar fram bland lastdjuren.

seger gå sig ur händerna, och inte heller lyssna på rådet att vänta på förstärkningar. Han marscherade mot den slätt där goterna ställt upp sina vagnar i cirkel och nådde dit den 9 augusti. Det var en stekhet dag och soldaterna var trötta efter en forcerad marsch medan goterna som ställt upp på en ås framför vagnborgen var utvilade och stridsberedda. Valens gjorde misstaget att inte anfalla genast och när striden väl kom igång var det genom en oplanerad incident. Detta störde den romerska slagordningen och katastrofen blev fullständig då en ny gotisk-alansk ryttarstyrka plötsligt dök upp på stridsskådeplatsen och högg in på romarna. Ena flygeln skars av, omringades och slaktades varpå det var den romerska centerns tur. Sent på eftermiddagen bröt disciplinen ihop fullständigt och ett antal romerska generaler fann för gott att fly fältet så snabbt tygeln höll. Valens själv föll för en pil eller brändes levande i en bondstuga där han låg sårad, vilken version man nu väljer att tro på. Två generaler, en tribun och två tredjedelar av hären föll för goternas vapen. Detta var något chockerande nytt i Romarrikets långa historia. För första gången hade främmande inkräktare inte bara segrat (det hade Hannibal gjort sex sekler tidigare) utan också kommit för att stanna. Tiotusentals goter var på drift på romersk mark och gjorde ingen min av att ge sig iväg. ${ }^{24}$

Den episka gotiska segern följdes av några års kaos på Balkanhalvön. För tillfället var ingen riktigt i kontroll över den östra rikshalvan. Segrarna härjade och plundrade i Moesien och Trakien och gjorde valhänta och misslyckade försök att ta först Adrianopel och sedan Konstantinopel självt. Under tiden tog sig chocken över katastrofen uttryck i ett uppflammande etniskt hat bland den grekisk-romerska befolkningen. Goter som tjänade

24 Ammianus Marcellinus, bok 31, i http://www.tertullian.org/fathers/ammianus 31 book31.htm (hämtad 15 november 2014). 


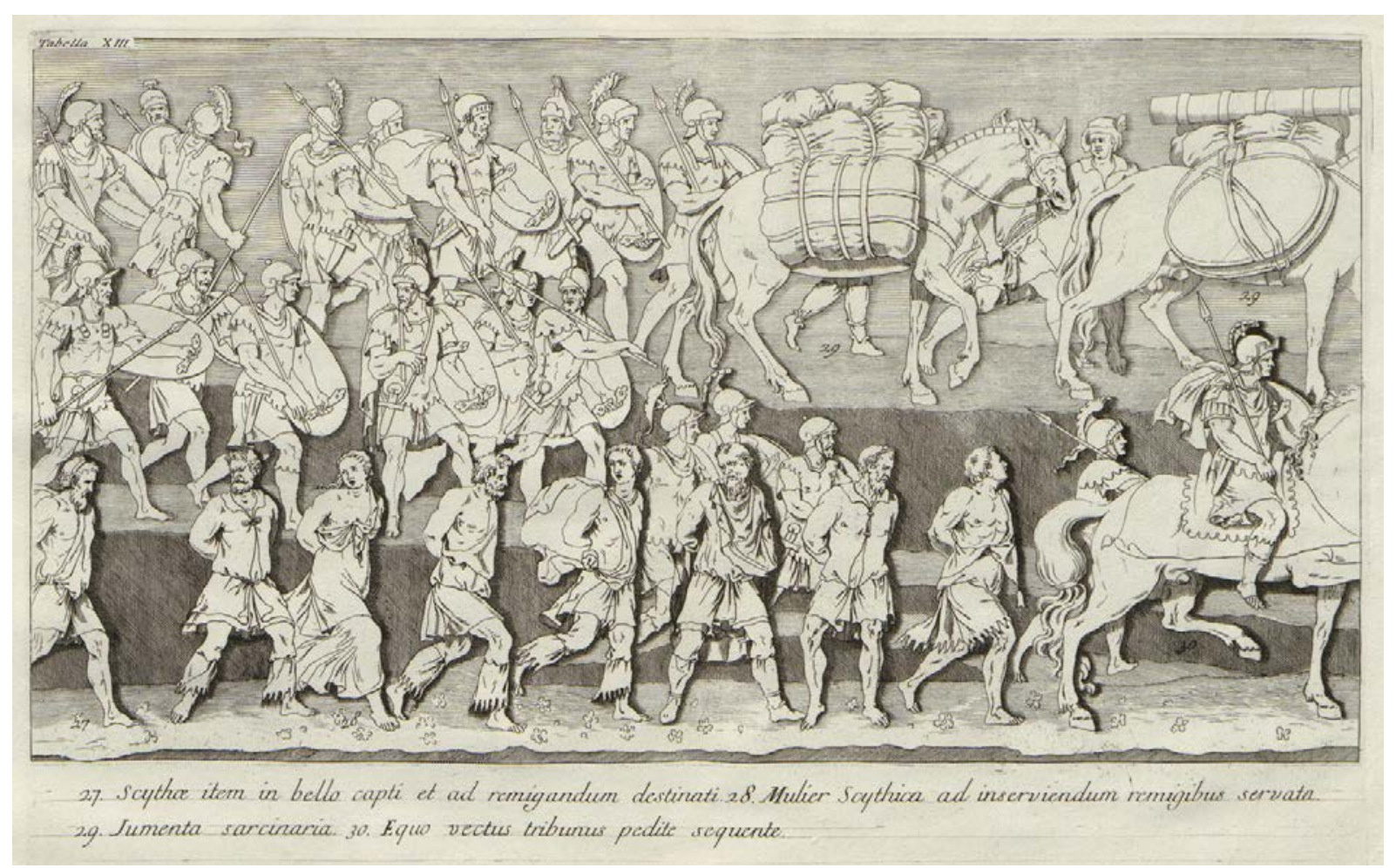

Bild 13. De romerska soldaterna föser fram sina skäggiga och byxbärande fångar.

i den romerska hären plockades ut och massakrerades. Ammianus Marcellinus som är den utförligaste källan för denna period skyllde rikets nergång på de kristnas fördärvliga inflytande, under det att katolska kristna skyllde på Valens kätterska sympatier. För moderna betraktare visar slaget vid Adrianopel att det klassiska romerska arméväsendet hade sett sina bästa dagar - även om idéer om att det skulle symbolisera det tunga kavalleriets triumf över infanteriet är överdrivna och missledande.

\section{Under den theodosianska eran}

Den västlige kejsaren Gratianus, Valens brorson, hade händerna fulla med bråkiga alemanner vid Galliens gränser och hade inte tid med gotiska affärer. I det vakuum som uppstod i östra Romarriket trädde istället en ny kraft med den spanske militären Theodosius, i historieböckerna känd som kejsar Theodosius den store. Namnet kommer sig mer av hans trohet mot den nicaeanska trosbekännelsen (det som blev den katolska kristendomen) än hans administrativa och militära dygder. Sant är dock att han var den siste som lyckades samla Romarriket till en helhet innan den definitiva uppdelningen mellan Östrom och Västrom efter hans död. Theodosius inbjöds att bli medkejsare i öster i januari 379 och tog resolut itu med att reda upp den trassliga politiska situationen. Från sin bas i Thessalonika i Grekland började han rekrytera soldater och sätta hårt mot hårt mot de gotiska marodörerna. En av hans generaler var själv en got, Modares. Några skrupler mot att kämpa mot stamförvanter visade inte denne då han vann en begränsad seger mot en gotisk trupp. Theodosius själv var måttligt framgångsrik i sina operationer. I spetsen för sina oövade rekryter led han ett försmädligt nederlag mot fienden år 380. Goterna 
blev nu än djärvare och tvingade städerna i norra Grekland att betala tribut till dem. Efter ytterligare ett par år av strider med växlande lycka blev det klart för Theodosius att goterna inte kunde köras bort från romersk mark. Han slöt ett fredsavtal med dem i oktober 382. Det är inte mycket vi vet om innebörden i avtalet; de samtida författarna påstår i vaga ordalag att barbarerna tilldelades land och fredligt började odla jorden i provinserna nordväst om Konstantinopel. Klart är i alla fall att de gotiska härjningarna upphörde. Helt lugnt var det dock inte under de kommande åren. En greutungisk furste vid namn Odotheus bröt in i Romarriket år 386, möjligtvis på flykt undan hunnerna. Han besegrades dock prompt av en romersk armé och miste livet. Kejsaren själv verkar ha tagit en aktiv del i operationerna och kunde dra in i Konstantinopel i triumf i oktober detta år. ${ }^{25}$

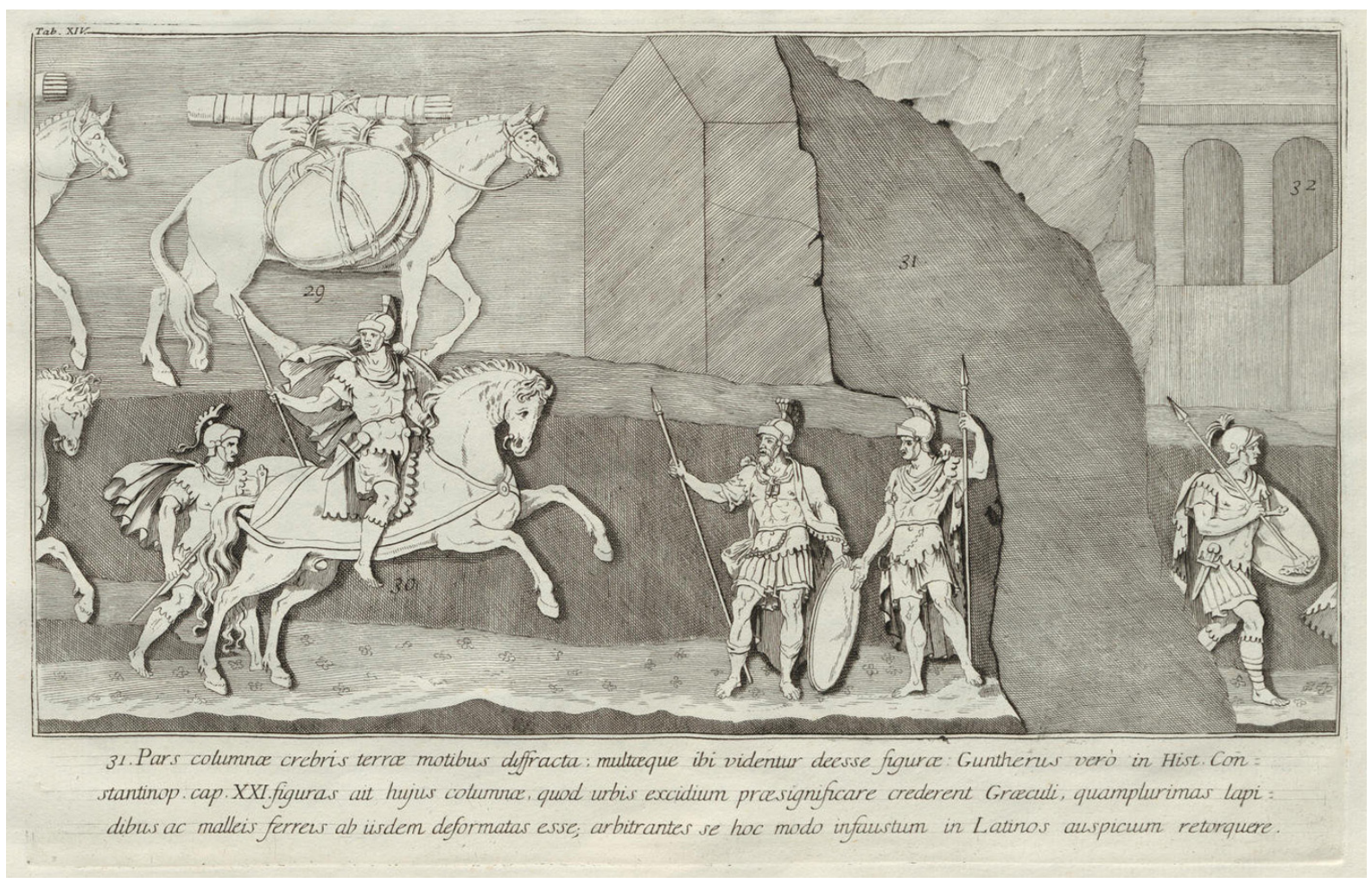

Bild 14. En beriden soldat föregår tåget av fångar.

Theodosius dog av naturliga orsaker i januari 395 efter att i ett knappt halvår ha varit ensam romersk kejsare. Hans bägge söner Honorius och Arcadius efterträdde honom i den västra respektive östra riksdelen och den här gången blev delningen permanent. Ingen av dem var någon större begåvning utan dominerades av starkare män och kvinnor i sin omgivning. Honorius regering skulle visa sig bli en okvalificerad katastrof för kejsardömet i väster under det att östriket under Arcadius stod rycken trots svåra törnar. Som vi sett talar källorna om två huvudgrupper av goter: tervinger som bildade huvudbasen för visigoterna (eller, som vi säger, västgoterna) och som i stor utsträckning flydde över gränsen 376, samt greutungerna som till en del kom att transformeras till ostrogoterna eller östgoterna och som i stor utsträckning levde under hunnisk överhöghet 25 Sande 1981, sid 42. 
men delvis slöt sig till migranterna söder om gränsen. Som om inte detta var invecklat nog ser vi under de sista åren av 300-talet en ny uppdelning, den här gången av de migranter som kommit in på romerskt territorium och efter 382 accepterade kejsarens överhöghet. Två figurer skulle komma att spela en stor och blodbestänkt roll här, den ena framgångsrik och ännu åtnjutande en viss världshistorisk berömmelse, den andra tragisk och idag blott ihågkommen av experter på senantikens historia. Deras olika öden har också att göra med frågan om varför det västromerska riket gick under medan det östromerska kom att leva kvar fram till 1453 (eller 1922 med tanke på de osmanska sultanernas titulatur som "kejsare av Rom”).

Den mer kände är Alarik, Roms erövrare och grundare av ett kungarike som senare skulle utveckla sig till den första spanska staten. Enligt en långt senare uppgift tillhörde

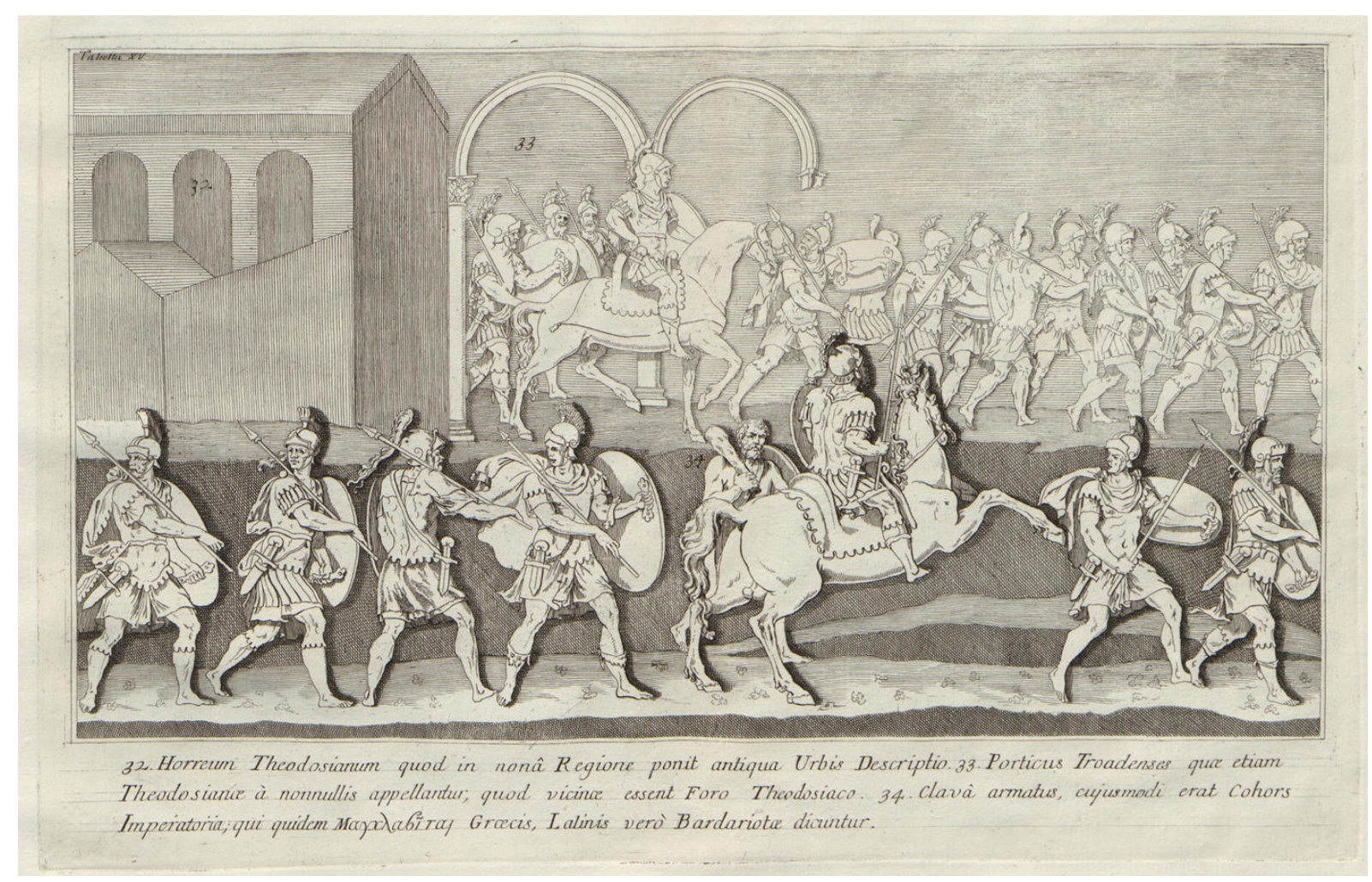

Bild 15. Romerska soldater i paraduniformer passerar Konstantinopels praktbyggnader, samman med en klubbeväpnad barbar.

han en aristokratisk släkt vid namn balterna, men de samtida källorna tyder på att han var en homme nouveau, en av de banditer eller rebeller som försökte göra sig en framtid på Balkanhalvön i det oroliga sena 300-talet. Han dyker upp i källorna 391 då han tycks ha ingått $i$ en rebellgrupp som konfronterade Theodosius vid floden Maritsa (i Bulgarien-Grekland). Snart därpå bytte han sida och kom han att ingå i de hjälptrupper som hjälpte Theodosius att ta makten i Italien 394. Nästa år sändes han tillbaka mot öster i spetsen för en arméenhet men kände sig missnöjd med att han inte tilldelats ett högre befäl och revolterade. Troligtvis samlade han under sig de flesta av de tervinger och greutunger som slagit sig ner i imperiet efter 382. Därmed börjar en femtonårig 
serie av marscher och strider som vi blott kan följa här i största korthet. ${ }^{26}$ Efter några år av förhandlingar och strider med varierande framgång lämnade han Balkanhalvön med sina skaror och trängde in i Italien 401. Trots att han drevs tillbaka till Balkan av den företagsamme generalen Stilicho kom rivaliteten mellan de bägge rikshalvorna och andra barbarinvasioner att spela Alarik i händerna. Från sin bas i Illyrien drog han mot Italien igen år 407. Kejsar Honorius förstörde sina chanser att hejda den gotiska anstormningen genom sin misstro mot Stilicho som han trodde planerade att själv anta den kejserliga purpurn. Stilicho avrättades och många av hans germanska hjälptrupper slöt sig till Alariks skaror vilket drastiskt försämrade säkerhetsläget för västriket. Därmed var scenen satt för den famösa erövringen av Rom den 24 augusti 410, den första främmande erövringen av staden på 797 år. För de gotiska segrarna fanns ett och annat att plocka på sig som samlats i staden under århundradenas lopp. Även om Alarik dog av naturliga orsaker strax därpå var han en märkesfigur i Europas historia. Dittills hade barbariska ledare opererat i skuggan av Roms makt, men Alarik visade att det var fullt möjligt att etablera sig som makthavare inom Romarrikets gränser utan att absorberas av det kejserliga styrets strukturer. ${ }^{27}$ Han skulle snart följas av en uppsjö av vandaliska, svebiska, gepidiska, frankiska, rugiska och burgundiska härkungar som under 400-talet bildade välden på mark som tills nyligen tillhört Romarriket.

Men goter fanns alltså också i och omkring Konstantinopel i öst. Många var integrerade i det romerska arméväsendet men höll ändå dörren öppen för en möjlig "barbar”karriär om tillfälle bjöds. Naturligtvis var inte alla goter respekterade militärer, utan det fanns också gott om fattiga lantbrukare och slavar på östromersk mark som lätt skulle kunna aktiveras. Alariks framgångar som gotisk folkledare och krigare undgick inte att göra intryck även på de som höll sig utanför hans brokiga skaror. En av de som gick Östroms ärenden var greutungen Tribigild som ledde en beriden avdelning i Frygien i Mindre Asien. Han gjorde god tjänst då östromarna hade en sammanstötning med hunnerna 398 men när han inte fick den belöning han tyckte sig förtjäna gjorde han prompt uppror efter samma mönster som Alarik. Med sina kavalleristyrkor härjade han i Mindre Asien tills han lockades i en fälla av en lokal milisstyrka och besegrades i grund. Med knapp nöd kunde Tribigild galoppera bort med 300 överlevande följeslagare eftersom en romersk officer visade sig vara en mutkolv och släppte igenom honom. Det fanns en uppenbar fara med att fylla ut arméerna med germaner eftersom de sällan hade långt till att byta sida.

Då Tribigild återigen började skörda framgångar skickade kejsarhovet i Konstantinopel en ny härförare att ta itu med marodören. Det var Gainas, en västgot som dock inte hade någon brådska med att försöka fånga Tribigild. Tvärtom medlade han mellan Tribigild och kejsarhovet som bekvämade sig med att avsätta en impopulär minister för att blidka den farlige upprorsmannen. Men inte heller det hjälpte i längden. Efter en tid, under vintern 399-400, lät Gainas masken falla och anslöt sig till de upproriska.

26 Wolfram 1990, sid 139-49.

27 Kulikowski 2007, sid 157. 
Tribigild omkom snart i kampen men Gainas började profilera sig som ledande kraft i det Östromerska väldet. Med sina soldater närmade han sig Konstantinopel och begärde att bli utnämnd till konsul och få en hög militär rang för att inte gå löst på staden. Han blev verkligen gjord till konsul av det förskrämda hovet och började styra och ställa i Konstantinopel efter eget gottfinnande. Någon Alarik var han emellertid inte trots att han ockuperade en romersk huvudstad liksom Alarik skulle göra tio år senare. Hans sätt att hantera makten präglades av kortsynthet och han retade upp stadsbefolkningen genom att favorisera den arianska versionen av kristendomen som kejsarmakten sedan

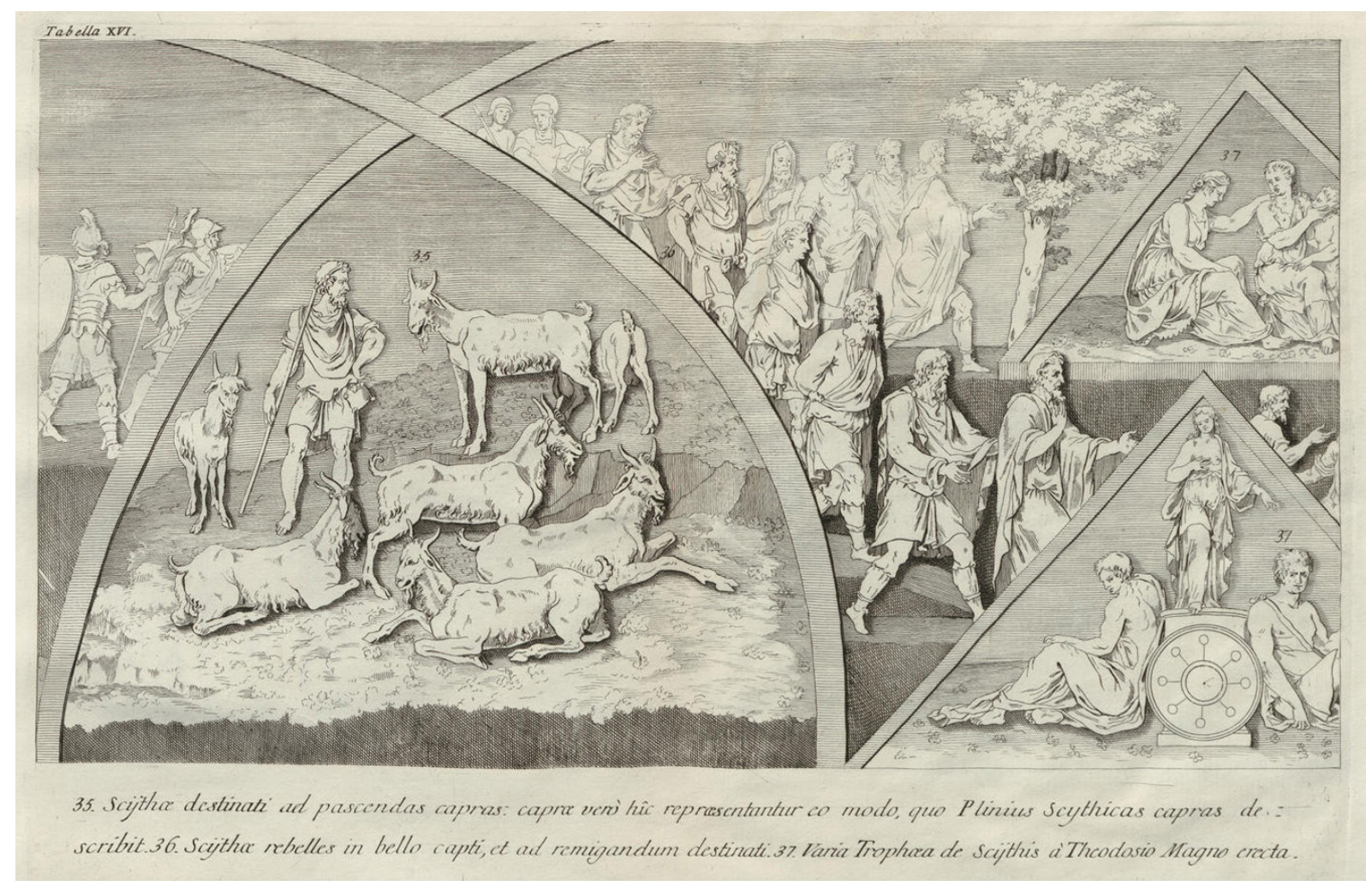

Bild 16. En stillsam herdescen samt ytterligare barbarer, kanske hövdingar.

länge dömt ut som kättersk. Till slut utbröt ett allmänt tumult i Konstantinopel. Gainas fann att han helt tappat greppet om situationen och smög sig iväg från staden, men 700 goter som blivit kvar flydde till en kyrka där de blev innebrända eller nerhuggna på kejsar Arcadius order. ${ }^{28}$ Gainas själv var nu en fredlös och hemlös krigare som med sina återstående skaror började plundra i Trakien på den europeiska sidan. Detta visade sig dock mindre lukrativt än han hoppats; skörden hade redan bärgats och befann sig i tryggt förvar i befästa städer. När han återigen försökte komma över till Mindre Asien besegrades han av en annan got som stod i romersk tjänst, Fravitta. ${ }^{29}$ Goterna som försökte ta sig över Hellesponten med småbåtar och flottar blev ett lätt offer för de romerska här-

28 Wolfram 1990, sid 149.

29 Den danske folkminnesforskaren Niels Lukman (1981) har framfört den starkt spekulativa hypotesen att Fravitta är ursprunget till den danske sagokungen Frode, samt att ytterligare ett stort antal folkvandringstida figurer skulle ha transponerats till den nordiska sagofloran. 
skeppen. Med sina sista följeslagare retirerade Gainas mot nordväst, bort från romersk mark. Dock blev han upphunnen och dödad av den hunniske härskaren Uldin i december 400. Hunnerna skickade tillmötesgående hans huvud till kejsarhovet där det bars genom gatorna på en stång. ${ }^{30}$

Alltså: medan Alarik hör till historiens "segrare” hör Gainas till dess "förlorare”. De våldsamma händelserna 399-400 ledde till en politisk kursändring som möjligen bidrog till att bevara det Östromerska riket för de kommande dryga tusen åren. Det förespråkades att barbarer i fortsättningen inte skulle användas för några högre poster i samhället. Det var alltför farligt att fylla ut legionernas led med goter och andra främlingar. Det här kanske inte skall tolkas i moderna termer av etniska motsättningar eftersom människor under senantiken tenderade att agera utifrån individuella intressen eller maktklickar snarare än föreställningar om inneboende skillnader mellan folkgrupper. Men med Gainas död fick i alla fall det östliga imperiet en respit och kunde börja bygga upp ett fungerande civilt styre igen. ${ }^{31}$

\section{Att känna igen en got}

I de i allmänhet inte speciellt utförliga källorna fladdrar de förbi, dessa goter som stjälpte stora delar av det Västromerska riket över ända och var på vippen att dominera även det Östromerska. Men vilket intryck gjorde de på dem som mötte dem? Hur uppförde de sig i samvaron med folk som präglats av grekisk-romersk kultur? Hur såg de ut? Det är frågor som är lättare att ställa än att besvara. Historieskrivningen gör en kvalitetsmässig djupdykning i senromersk tid då vi befinner år ljusår från Titus Livius, Tacitus och Dio Cassius glansdagar, och det finns inga inspirerade etnografiska beskrivningar i stil med Tacitus Germania. Några intressanta fragment av mötet hittar vi hos tidsepokens poeter. En anonym diktare från Sydgallien, där västgoterna slog sig ner på 400-talet, beskriver kulturkrocken: "Ingen kan skriva hygglig poesi mitt bland goter som hela tiden ropar 'Hej, ge oss mat och dricka'”. En annan 400-talspoet, Apollinaris Sidonius, klagar likaledes över hur hans sex fots hexameter störs av sju fots barbarer. Han nämner som typiskt för goterna i Gallien att de var pälsklädda, även den västgotiske kungens egen livvakt. Han noterar också med vämjelse den hårpomada som goterna använde sig av, nämligen smör som snabbt blev härsket och gav barbarerna en distinkt odör. ${ }^{32}$ Det finns ett litet antal porträtt av gotiska kungar på mynt och medaljonger som visar långhåriga herrar prydda av en mustasch. Just denna detalj har ett visst intresse eftersom det verkar ha funnits ett mustaschmode under folkvandringstid som även går igen i Skandinavien. Man kan hänvisa till de berömda pressbleckspatriserna från Torslunda på Öland från yngre järnålder.

Karl Reinhard Krierer har i detalj undersökt hur den föreställande konsten har porträtterat germaner under den romerska kejsartiden. Det kan i sin tur jämföras med arkeologiska fynd. Som det visar sig uppkom på ett tidigt stadium en utpräglad idé om hur germanerna förväntades se ut, snarast som en fortsättning på motsvarande bilder av kelterna. Frågan är alltså hur noggranna etnografiska detaljer man kan förvänta sig på

30 Cameron \& Garnsey 1998, sid 116-17.

31 Cameron \& Garnsey 1998, sid 117.

32 Wolfram 1990, sid 210. 
reliefer, myntbilder, statyetter, mosaiker och annat. Svaret är att det varierar kraftigt över tiden. Den berömda Trajanuskolonnen i Rom visar ett fälttåg mot dakerna 101-106 e.Kr. och framställer förutom daker även germanska hjälptrupper. Relieferna präglas av en hög konstnärlig kvalitet och en viss etnografisk nyfikenhet (till exempel på bilderna av det dakiska drakemblemet eller de fjällpansarklädda sarmaterna). Nästa bevarade kolonn färdigställdes 193 och visar kejsar Marcus Aurelius krig mot markomannerna 166-180. Här är framställningen av barbarer uppenbart mer stereotyp än på Trajanuskolonnen. Senare konstföremål visar en än mer slätstruken bild av den barbariske andre. Germanerna framstår i den romerska konsten som skäggyviga drumlar med långt lockigt hår, ibland uppbundet i en så kallad sveberknut på ena sidan av hjässan. De bär rymliga byxor och kan antingen ha naken överkropp eller tunikor som kan vara ärmlösa eller långärmade, ibland med en kortärmad övertunika och en tung mantel. I strid bär de sköld, klubba, svärd och spjut men aldrig hjälm. ${ }^{33}$ Någon enstaka gång bär de en luva. Stridsscener visar dem alltid i militärt underläge. De trampas under de romerska kavalleristernas hästar, faller för infanteristernas svärd och lansar, ofta nästan utan att göra effektivt motstånd. Den romerska effektiviteten segrar över de vilda men ineffektiva barbarerna. Från den tid som vi här skildrar, 300- och 400-talen, finns dock väldigt få bevarade framställningar. ${ }^{34}$

Arkeologin ger en del besked. Speciellt i mossar i norra Tyskland och Danmark har man hittat byxor, tunikor, sköldar och annat som nära påminner om det man ser på de romerska relieferna. Även sveberknuten har man återfunnit på väl bevarade lik. ${ }^{35}$ Det berömda mossliket "Tollundsmannen” i Danmark har en luva som påminner om vissa avbildningar. ${ }^{36}$ För de stammar som rörde sig i Romarriket under folkvandringstiden vet man mindre eftersom få textilier har bevarats och det ofta är svårt att identifiera vilka etniska grupper som har använt vilka gravplatser. ${ }^{37}$ Men där kunskapen tryter får som bekant fantasin ofta spelrum. I illustrationer från 1800- och 1900-talen förses goter, vandaler och hunner med vapen, dräkter och håruppsättningar som inte har den ringaste koppling till existerande fynd eller beskrivningar. Men kanske man inte behöver ta till spekulationer. Istället kan man möjligen fråga hur pass intressant det över huvud taget är resonera i termer av etnicitet.

Den tyske forskaren Philipp von Rummel har nyligen tagit upp frågan om barbarernas yttre i en innehållsrik avhandling, Habitus barbarus. Kleidung und Repräsentation spätantiker Eliten im 4. und 5. Jahrhundert (2007). Han går i stor detalj igenom arkeologiska, konstnärliga och textuella belägg för folkvandringsstammarnas klädsel och frågar sig hur mycket de egentligen säger oss om ett specifikt barbariskt dräktskick såsom skilt från ett allmänt senantikt. Svaret lyder enligt Von Rummel: inte särskilt mycket. På enstaka bilder, till exempel de kända mosaikerna från Kartago i det vandaliska Nordafrika och porträttet

33 Under folkvandringstiden bars dock så kallade spangenhjälmar, kända från flera arkeologiska fynd. De var koniska med kindskydd och närmast inspirerade från skyters och sarmaters beväpning. För bilder på sådana, se http://commons.wikimedia.org/wiki/Spangenhelm?uselang=de (hämtat 20 november 2014).

34 Krierer 2004, med reproduktioner av kända germanbilder.

35 Döbler 1979, sid 498.

36 Döbler 1979, sid 338.

37 Döbler 1979, sid 339. 


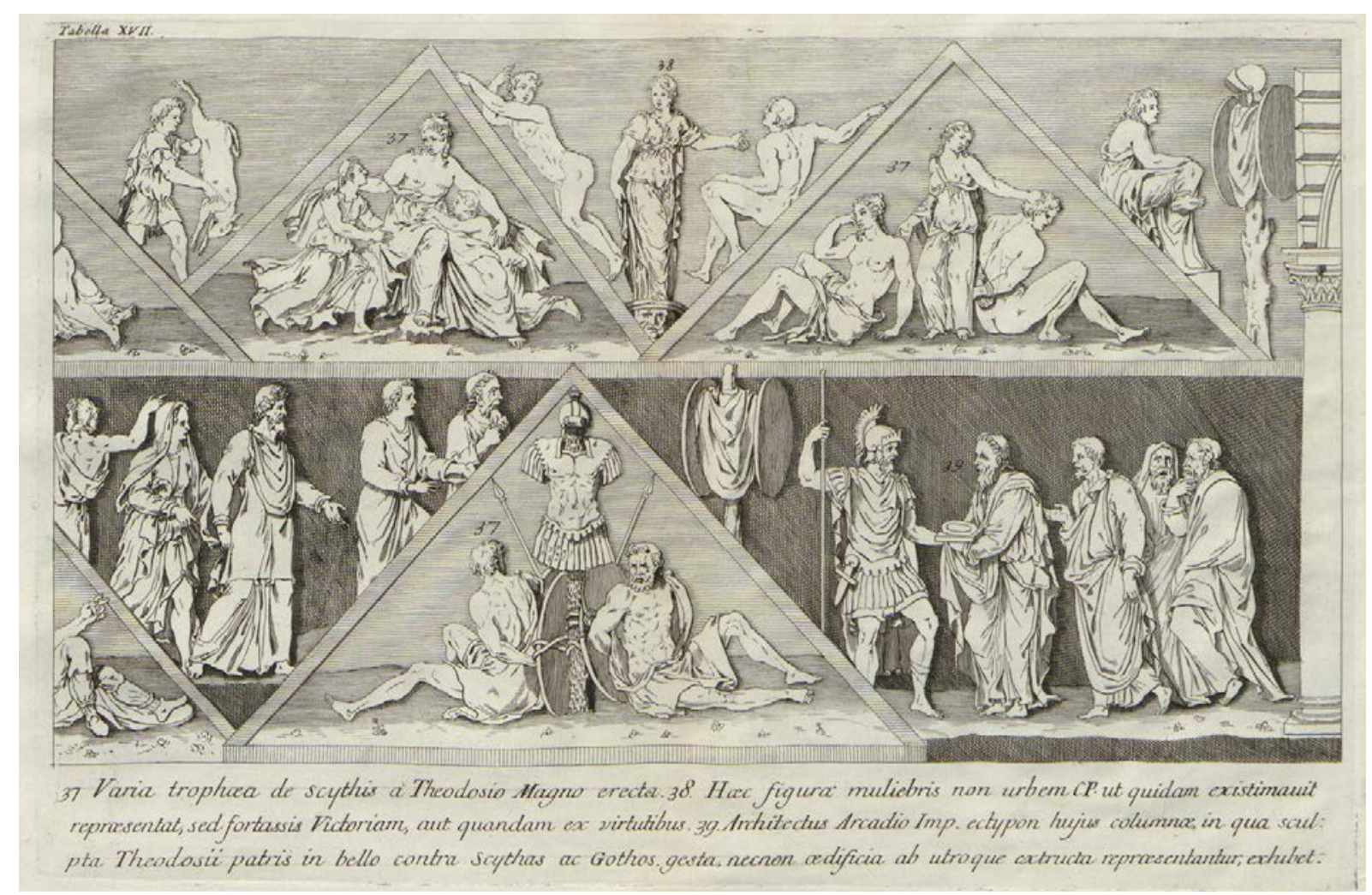

Bild 17. En rad symboliska segerbilder.

av den

ursprungligen vandaliske Stilicho från Monza, finner man långärmade tunikor, byxor och skäggiga frisyrer som ser allt annat än "romerska” ut och ofta tolkats som uttryck för germansk etnicitet. ${ }^{38}$ Men för Von Rummel är det snarare fråga om sociala än etniska distinktioner. De som skrev texter som bevarats för eftervärlden tillhörde det gamla civila elitskiktet och för dem representerade den nya militära eliten ett steg bakåt för civilisationen. Av den anledningen uttalade de sig kritiskt om pälsverk, skägg och annat som föreföll dem barbariskt, trots att dessa saker ingick i det senantika militära modet. Man ska alltså akta sig för att resonera i dualistiska termer romerskt-germanskt och etnicitet är enligt författaren ingen primär arkeologisk kategori. Von Rummel undslipper dock inte det vanliga problemet med forskare som vill ställa äldre hypoteser på huvudet: han måste bortförklara för mycket av senantika bilder och beskrivningar för att det ska kännas alldeles övertygande. Men klart är nog att de yttre skillnaderna mellan en "romare” och "barbar” under t.ex. slaget vid Adrianopel inte var självklara.

\section{Segerparaden igen}

Detta för oss tillbaka till bildrullen och kopparsticken. Vilken händelse under den theodosianska tidsåldern är det som visas, och rör vi oss överhuvudtaget med pålitliga avbildningar av de ursprungliga relieferna? Svaren på dessa frågor har varierat kraftigt från forskare till forskare.

38 Reproduktioner av dessa finns i Jones \& Ereira 2006, mellan sid 192/193. 


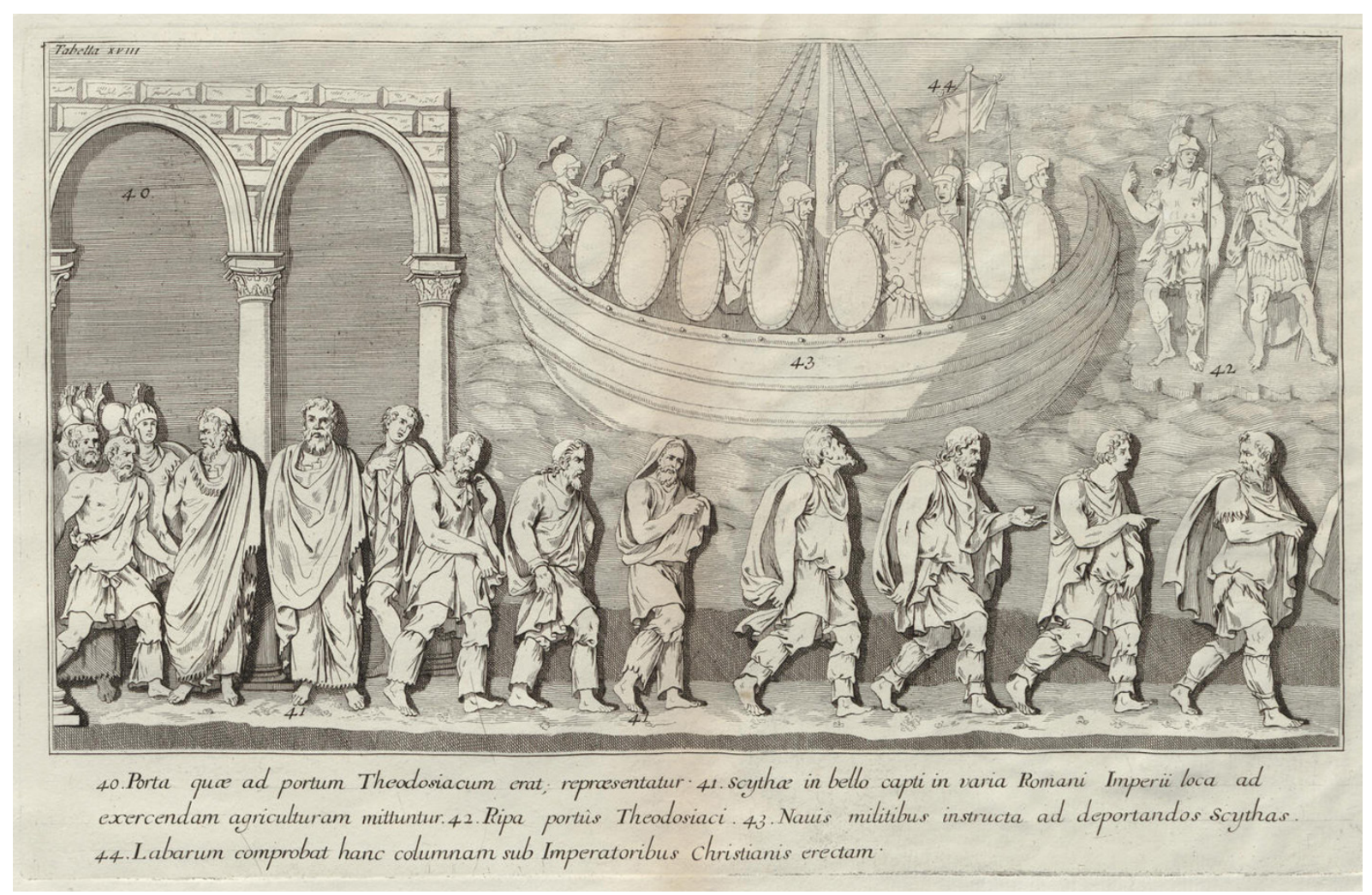

Bild 18. Sviten avslutas med en rad barbarer vid havsstranden (Bosporen?), livligt gestikulerande och diskuterande, måhända om vad som ska bli deras nästa öde.

Johannes Kollwitz (1903-1968) var en tysk katolsk teolog och därtill antikvetare som skrev en rad betydande arbeten om kristlig och senantik konst. ${ }^{39}$ Mitt under kriget, då han tjänade som själasörjade i en slottskyrka i Lippe, utkom hans stora arbete Oströmische Plastik der theodosianischen Zeit (1941). I sin utredning om Arkadiuskolonnen drog han nytta av två serier teckningar som utfördes under tidigmodern tid. Den ena är de så kallade Freshfieldteckningarna som utfördes 1574, den andra är teckningar från slutet av 1600-talet som finns bevarade i nationalbiblioteket i Paris. De senare gjordes vid en tid kolonnen var illa ankommen och de nedre reliefbanden knappt kunde urskiljas. De ger tillsammans en ungefär samstämmig idé om bildberättelsen som ringlar sig från basen mot toppen av kolonnen. Tyvärr är ingen av dem särskilt detaljerad och de många människofigurerna är bara skissartade. Vi ser ett tåg ur eller genom en stad, därefter ett sjöslag som följs av ytterligare strider och någon form av triumfscen. Kollwitz menade att det måste röra sig om kejsar Arcadius strid mot Gainas och hans goter år 400. Marschen som visas i början av reliefen är Gainas plötsliga uttåg ur Konstantinopel den 12 juli 400 med följeslagare, pick och pack. Den sjöburna striden är Gainas nederlag vid Hellesponten. På teckningarna ser man tydligt hur människor bygger flottar vid stranden och hur döda eller drunknande människor ligger i vattnet. Slutligen besegras Gainas sista trupper och kejsardömet har till slut triumferat såsom visas i toppen av kolonnen. ${ }^{40}$

39 Ulbert, 'Kollwitz, Johannes', Deutsche Biographie, http://www.deutsche-biographie.de/sfz44255. html (hämtat 14 november 2014).

40 Kollwitz 1941, sid 27-28. 
Kollwitz jämförde i detalj bildrullen från Louvren med teckningarna av Arcadiuskolonnen. Han menade att om man tittade riktigt noga fanns en del likheter mellan den nedre delen av kolonnen och Louvrenrullen. Problemet, menade Kollwitz, var att konstnären helt och hållet hade missuppfattat relieferna. Av det som egentligen var ett uttåg från en stad hade det blivit ett triumftåg. Implikationen var naturligtvis att de vackra och detaljrika teckningarna från Louvren inte var mycket att lita på. Å andra sidan observerade Kollwitz att en viss S. Schweigger som besåg kolonnen runt 1580 hade samma uppfattning som tecknaren: "På denna historiepelare ... är en kejsares triumf uthuggen". ${ }^{41}$

I senare tid har även Michael MacCormick berört frågan i sin studie av senantika triumfer och deras symbolik, Eternal victory (1986). Han konstaterar att skisserna från Louvren fortfarande väntar på en definitiv studie men anser i motsats till Kollwitz att de är signifikanta och inte så tvetydiga. Tydligen är det en kejsare eller romersk befälhavare som firar triumf - kanske är det goten Fravitta som marscherar in efter att ha besegrat sin stamförvant Gainas. ${ }^{42}$ Men precis som sin företrädare tror han att det är Arcadius momument som har avtecknats. Det finns olikheter mellan Louvrenskisserna och de andra teckningarna av Arcadiuskolonnen och det är enligt MacCormick oklart vilken, om någon, som är den mest korrekta. Men det finns faktiskt en omständighet som tyder på att Louvrenskisserna är trogna mot originalet. I en scen ser vi tre kameler på vilka man har bundit figurer. ${ }^{43}$ Vad det är för figurer är omtvistat; det skulle kunna röra sig om gudabilder men också om fångna hövdingar som man har bundit upp vid kamelernas pucklar - MacCormick anser det sistnämnda vara fallet. Nu användes kameler under senantiken för rituella förolämpningar. Antingen det nu rör sig om gudar eller fångna ledare ger alltså kamelerna en extra dimension åt deras förnedring. Eftersom kamelsymboliken knappast var känd under tidigmodern tid då skisserna gjordes, tyder det på att scenen är autentiskt senantik. ${ }^{44}$

Även i övrigt har Kollwitz rönt mothugg i sin tolkning av de gåtfulla skisserna. Italienaren Giovanni Becatti skrev ett annat stort arbete, La colonna coclide istoriata (Den spiralformade historiska kolonnen, 1960) där han kom fram till helt andra slutsatser. Efter en omfattande undersökning hävdade han att det i själva verket rör sig om de nedre reliefbanden på Theodosius kolonn som försvann i början av 1500-talet. Man kan tänka sig triumftåget efter segern mot Odotheus och greutungerna år 386. Det betyder i så fall att skisserna trots allt skulle återgå på äldre avbildningar av Gentile Bellini eller någon annan. Becatti påpekade att skillnaderna mellan Louvrenskisserna och Freshfieldteckningarna var större än likheterna och att de tydligen representerade besläktade men olika monument. Detaljer i skisserna tyder på att artisten har kunnat betrakta relieferna på nära håll. Becattis undersökning anses vara den mest uttömmande i ämnet och har fått

41 Kollwitz 1941, sid 22.

42 MacCormick 1986, sid 50.

43 Menestrier 1702, illustration IX.

44 MacCormick 1986, sid 49. 
en del medhåll. ${ }^{45}$ Frågan är dessutom om Kollwitz historiska tolkning av Arcadiuskolonnen är riktig. Att ett segermonument skulle visa ett långt uttåg av fientliga trupper som upptar nästan halva kolonnen, nämligen Gainas och hans goter år 400, verkar inte så troligt. Snarare rör det sig även här om ett triumftåg fast det inte är klart och tydligt i de vagt gjorda Freshfieldteckningarna (eller teckningarna i Paris nationalbibliotek som alltså gjordes vid en tid då de nedre reliefbanden nästan var förstörda). ${ }^{46}$

År 1973 började de turkiska myndigheterna bygga ett nytt bibliotek för Istanbuls universitet. Intressant nog hittade man då ett antal marmorblock med reliefer som såg antika ut. Nu visste man att det en gång funnits ett senromerskt forum på denna plats som Theodosius hade invigt år 393. På detta Forum Tauri stod bland annat kejsarens triumfkolonn. Det förmodades att sultanen Bayazid II (1481-1512) hade använt sig av de antika marmorbitarna från kolonnen när han byggde sitt eget komplex på platsen. En konstvetare vid namn Siri Sande har undersökt de nya relieffynden och hittat en del intressanta likheter med Louvrenteckningarna. Precis som i skisserna verkar den som designat relieferna ha lagt sig vinn att göra scenerna så varierade som möjligt. I en scen ser vi betande hästar som motsvarar illustration VIII i Ménestrier. Ett annat relieffragment visar en man, möjligen bland packhästar som svingar en klubba, vilket är snarlikt illustration $\mathrm{XV}^{47}$ Det är möjligt att vi i framtiden kommer att hitta fler fragment som kan ge svaret på hur kolonnernas reliefscener var upplagda. Samtidigt visar fragmenten med önskvärd tydlighet att man får vara försiktig med att använda Louvrenillustrationerna som historiskt källmaterial för annat än sin egen samtids antikvariska intressen speciellt om det finns ett mellanled mellan dem och ursprungsrelieferna. Både hästarna och mannen med klubban är ganska fritt återgivna. Siri Sande har dragit slutsatsen att konstnären ser ut att ha återgivit de enskilda figurerna korrekt som typer, men att mindre detaljer har lagts till eller omformats. Hans egen konstnärliga skolning påverkade honom säkert. ${ }^{48}$

Hur är det då med de gotiska fångarna - antingen det nu rör sig om de greutunger som föstes genom Konstantinopels gator den 12 oktobet 386 eller överlevarna från Gainas äventyr runt nyåret 400/401? Kan deras yttre säga oss någonting vi inte redan vet? Som de framstår på Louvrenskisserna överensstämmer de i stora drag med andra avbildningar av germaner från tidigare sekler, dock med vissa variationer. De skäggiga männen bär tunikor som kan vara ärmlösa, kort- eller långärmade, precis som på Marcus Aurelius kolonn i Rom. Ofta är ärmarna uppkavlade. Bårderna är ibland mönstrade, till exempel hos den långskäggige hövding som sitter med sina underlydande på en vagn (illustration III). Tunikorna knäppes i allmänhet framtill och har kragar, i motsats till äldre avbildningar eller nordtyska mossfynd. ${ }^{49}$ Tunga mantlar bärs i många fall. Byxorna

45 Becatti 1960, sid 111-50, summerat av Sande 1981, sid 73-74.

46 Sande 1981, sid 74.

47 Sande 1981, sid 4, 31, 73-77.

48 Sande 1981, sid 77.

49 Döbler 1979, sid 337. 
är ofta vida och fransiga nertill vilket även det skiljer sig från äldre framställningar. De kan också vara barbenta och barfota. Flera kvinnor och barn förekommer i tåget. Kvinnorna har, liksom på Tacitus tid, ärmlösa vida dräkter och ibland huvuddukar och några av dem har ena bröstet blottat. ${ }^{50}$

Men man ska akta sig för att dra för stora växlar på skillnaderna mellan "barbar” och "icke-barbar”. Det är troligt att många av soldaterna och svennerna i tåget också är av germanskt ursprung. Ett relieffragment som inte har någon motsvarighet i Louvrenskisserna visar hur soldater ger upp i samband med en militär konfrontation. Av allt att döma rör det sig om goter. Soldaterna är klädda i långärmade tunikor men bär vanliga romerska hjälmar och verkar vara slätrakade. ${ }^{51}$ Det understryker åter det som Von Rummel varit inne på: skillnader i dräktmode i Medelhavsområdet hade vid denna tid mer med sociala än etniska skillnader att göra.

Det är kanske inte så konstigt att Louvrenskisserna eller kopparsticken i Banduris och Ménestriers verk nästan aldrig syns i världshistoriska textböcker eller verk om folkvandringstidens historia - trots den skriande bristen på autentiska bilder av folkvandringstida stammar. Det finns för många osäkra faktorer för att de ska kunna reproduceras för den historieintresserade allmänheten med påståendet att "så såg goterna ut”. Men bilderna är vackra och välgjorda och förmedlar en fantasieggande föreställning om den senantik som vi vet så lite om. Det mesta tyder på att konstnären har använt sin egen tids estetiska och antikvariska ideal för att ge liv åt de senantika relieferna. Men sista ordet är säkert inte sagt. Förhoppningsvis kommer framtida fynd att fylla ut vår kunskap om hur den theodosianska erans konstnärer valde att framställa dessa goter på drift.

\section{Referenser}

Ammianus Marcellinus (n.d.), Roman history, book 31, www.tertullian.org/fathers/ ammianus 31 book31.htm (hämtat 15 november 2014).

Banduri, Anselma (1711), Imperium orientale. Paris.

Beccati, Giovanni (1960), La colonna coclide istoriata. Roma.

Behre, Göran, Larsson, Lars-Olof \& Österberg, Eva (2001), Sveriges historia 1521-1809; Stormaktsdröm och småstatsrealitet. Stockholm.

Cameron, Averil \& Garnsey, Peter (1998), The Cambridge ancient history, Volume 13; The late Empire, $A D$ 337-425. Cambridge.

Döbler, Hannsferdinand (1979), Die Germanen; Legende und Wirklichkeit. München. Jones, A.H.M. (1975), The decline of the ancient world. London \& New York. Jones, Terry \& Ereira, Alan (2006), Barbarerna: Romarrikets historia ur de erövrade folkens perspektiv. Stockholm.

Jordanes (1997), Getica; Om goternas ursprung och bedrifter. Stockholm.

Kollwitz, Johannes (1941), Oströmische Plastik der theodosianischen Zeit. Berlin. Krierer, Karl Reinhard (2004), Antike Germanenbilder. Wien.

50 Jämför Döbler 1979, sid 339.

51 Sande 1981, sid 43. 
Kulikowski, Michael (2007), Rome's Gothic Wars: From the Third Century to Alaric. Cambridge.

Lukman, Niels C. (1981), Frode Fredegod - den nordiske Fravita. København.

Lönnroth, Lars (1995), Isländska mytsagor. Stockholm.

MacCormick, Michael (1986), Eternal victory; Triumphal rulership in late antiquity. Cambridge \& Paris.

Ménestrier, Claude-François (1702), Columna Theodosiana quam vulgo historiatam vocan ab Arcadio Imperatore Constantinopoli erecta in honorem imperiatoris Thedosii junioris a Gentile Bellino delineata. Paris.

Rummel, Philipp von (2007), Habitus barbarus. Kleidung und Repräsentation spätantiker Eliten im 4. und 5. Jahrhundert. Berlin \& New York.

Sande, Siri (1981), 'Some new fragments from the column of Theodosius', Acta ad Archaeologicam et artium historiam pertinentia 1, sid 1-78.

Ulbert, Thilo (n.d.), 'Kollwitz, Johannes', Deutsche Biographie, www.deutsche-biographie. de/sfz44255.html (hämtat 15 november 2014).

Wolfram, Herwig (1990), History of the Goths. Berkeley. 